\title{
PENUBUHAN DAN PERKEMBANGAN \\ PERSEKUTUAN MELAYU MESIR (PMM), 1956-1964
}

\author{
Muhammad Hafiz Samsudin \\ Abu Hanifah Haris
}

\begin{abstract}
Persekutuan Melayu Mesir (PMM) is one of the earliest Malay student associations in Cairo. History of the earliest Malay student association in Cairo can be traced to the early 1920s, but PMM was officially launched in 1956. PMM was a very active and influential association among the Malay students in Cairo in the late 1950s and early 1960s. This association still exists until today with the new name Persekutuan Melayu Republik Arab Mesir (PMRAM). Although PMM was an influential Malay student association in Cairo, very little is known about it. This article discusses the establishment of PMM and its development from 1956 to 1964. In particular, the study shows that the administration of PMM was carried out systematically by its members. The association has its own rules, annual structure of organization, and a complete information about the number of its members. The study also uncovered that the students' hectic schedules did not stop them from administering PMM efficiently for the welfare of their own members.
\end{abstract}

\section{Pengenalan}

Sebelum abad ke-19, Makkah merupakan tumpuan orang Melayu mendalami pengajian ilmu agama. Ini kerana Makkah sendiri adalah tempat bermulanya perkembangan agama Islam dan umat Islam setiap tahun mengerjakan ibadat haji di sana. Bermula pada abad ke-19 Masihi, 'kiblat pengajian ilmu agama' umat Islam telah beralih ke Mesir terutamanya di Universiti alAzhar di Kaherah. Ramai sarjana Islam menegaskan bahawa kaedah dan bentuk sistem pengajian ilmu-ilmu Islam yang dijalankan di Universiti al-Azhar adalah lebih baik dan bersesuaian dengan pendekatan moden, berbanding dengan apa yang diajar di institusi pengajian tinggi di Makkah. Walaupun terdapat banyak institusi pengajian di Mesir selain Universiti al-Azhar pada awal abad ke-20 Masihi seperti Dar al-Ulum (1871), Universiti Kaherah (1908) dan Universiti 'Ain Shams (1950), tetapi Universiti al-Azhar adalah institusi pengajian yang paling masyhur dan popular.

Walaupun sejarah mengenai pemergian orang Melayu ke Mesir untuk mendalami pengajian Islam boleh dijejaki seawal abad ke-17 Masihi, tetapi timbulnya kesedaran dalam kalangan pelajar Melayu di sana untuk menubuhkan persatuan sendiri hanya berlaku pada awal tahun 1920-an. Jika dilihat kajian-kajian sebelum ini yang berkaitan dengan kegiatan pelajar Melayu di Kaherah, kebanyakannya hanya mengkaji tentang persatuan pelajar Melayu di sana sebelum Perang Dunia Kedua dan amat sedikit kajian yang membincangkan mengenai persatuan pelajar Melayu pada era 1950-an dan 1960-an terutamanya berkenaan Persekutuan Melayu Mesir (PMM).

\section{Latar Belakang Persatuan Pelajar Melayu di Kaherah}

Pelajar-pelajar Melayu di Mesir mula menubuhkan persatuan pada tahun 1923 dengan penubuhan Persatuan Kebajikan Pelajar-Pelajar Jawi Universiti al-Azhar (Al-Jam'iyyah AlKhairiyyah li Talabah al-Azhariyyah al-Jawiyyah). Persatuan ini menghimpunkan semua pelajar Melayu dari seluruh Alam Melayu seperti Semenanjung Tanah Melayu, Hindia Timur 
Belanda (Indonesia), Borneo dan Selatan Thailand. Walau bagaimanapun, persatuan tersebut lebih didominasi oleh pelajar Melayu dari Indonesia.

Pada akhir tahun 1920-an, persatuan tersebut lebih condong ke arah pemikiran politik yang radikal. Ini dapat dilihat menerusi penulisan mereka dalam penerbitan lidah rasmi persatuan itu iaitu majalah Seruan Azhar dan Pilehan Timoer. Ini menyebabkan perbezaan fahaman dalam kalangan ahli seterusnya menimbulkan perpecahan. Perpecahan tersebut telah menyebabkan sebilangan ahlinya, iaitu pelajar-pelajar Semenanjung Tanah Melayu keluar daripada persatuan tersebut dan menubuhkan persatuan baharu yang dinamakan Persekutuan Putera-Putera Semenanjung (PPS).

Menurut kajian Md. Sidin Ahmad Ishak dan Mohammad Redzuan Othman, PPS ditubuhkan pada 10 April 1932 dengan perlantikan Tuan Ismail Ali Syamsuddin sebagai Yang Dipertua PPS yang pertama, Shaykh Yahya Zakaria sebagai Timbalan Yang Dipertua dan Naim Taib sebagai Setiausaha Agung persatuan yang pertama. ${ }^{1}$ Walau bagaimanapun, berdasarkan sumber daripada rekod Arkib Negara Malaysia dan Persekutuan Melayu Republik Arab Mesir (PMRAM), PPS telah ditubuhkan dua tahun lebih awal daripada tarikh tersebut iaitu pada 11 April $1930 .^{2}$ Bahkan dalam logo rasmi PMRAM, tertera tahun 1930 sebagai tahun penubuhan persatuan. ${ }^{3}$ Menurut sumber daripada rekod PMRAM juga, Tuan Ismail Ali Shamsuddin merupakan Yang Dipertua PPS yang kedua. ${ }^{4}$ Rekod tersebut menyatakan bahawa Yang Dipertua PPS yang pertama ialah Tuan Amin Nuruddin Jemain, pelajar Melayu yang berasal dari Perak. ${ }^{5}$

Berdasarkan rekod-rekod tersebut, ini jelas membuktikan bahawa PPS telah ditubuhkan seawal tahun 1930 lagi. Antara tokoh lain yang terlibat dalam pengasasan PPS ialah Shaykh Fadhlullah Suhaimi, ${ }^{6}$ Shaykh Hussin Abbas, ${ }^{7}$ Shaykh Ahmad Ataullah Suhaimi, ${ }^{8}$ Shaykh Muhammad Saman, ${ }^{9}$ Shaykh Abdul Halim Othman, ${ }^{10}$ Abdul Jalil Hassan, ${ }^{11}$ Muhammad Nasir Jauhari, ${ }^{12}$ Tuan Hj. Ismail Hj. Hamzah, ${ }^{13}$ Salleh Othman, ${ }^{14}$ Shaykh Hamzah Mu'ti ${ }^{15}$ dan Tamim Sari.

Satu sumber dari rekod fail Setiausaha Kerajaan Negeri Terengganu menyatakan bahawa PPS pernah menghantar satu memorandum kepada Majlis Raja-Raja bagi memohon dana untuk pembinaan sebuah bangunan asrama yang khusus untuk pelajar-pelajar Persekutuan Tanah Melayu di Kaherah. Dalam memorandum tersebut ada menyatakan bahawa PPS pada asalnya merupakan sebuah persatuan yang ditubuhkan oleh sekumpulan pelajar daripada negeri Johor yang menuntut di Kaherah untuk menjaga kepentingan kumpulan mereka di sana. Walau bagaimanapun, persatuan tersebut mula disertai oleh pelajar-pelajar daripada seluruh negeri Semenanjung Tanah Melayu. ${ }^{16}$

Berdasarkan rekod surat-menyurat, PPS boleh dihubungi melalui surat di dua tempat di Kaherah iaitu di Ruwaq Indonesia al-Azhar dan di Rumah Johor yang beralamat di No.7, Shari' Ibrahim Pasha. ${ }^{17}$ PPS ditubuhkan bertujuan untuk menjaga kebajikan pelajar-pelajar Semenanjung Tanah Melayu di Mesir terutamanya untuk membantu mereka yang mengalami masalah kewangan yang boleh menjejaskan pengajian mereka. ${ }^{18}$ Untuk itu, PPS telah berusaha mengumpul derma daripada masyarakat Islam di Semenanjung Tanah Melayu untuk meringankan beban kewangan pelajar demi kelangsungan pengajian mereka di Mesir.

Selain membantu pelajar-pelajar Semenanjung Tanah Melayu yang berada dalam kesusahan, PPS juga memainkan peranan dalam memberi kesedaran kepada mereka supaya berusaha keras selain sentiasa bekerjasama dan bersatu dalam persatuan. ${ }^{19}$ PPS juga telah menubuhkan Panitia Rumah Melayu pada tahun 1932 bagi menyelenggara rancangan pembinaan sebuah bangunan asrama di Kaherah khas untuk pelajar-pelajar Melayu. Sehingga tahun 1955, PPS telah ditadbir oleh 14 orang Yang Dipertua atau Presiden. Antara mereka yang paling menonjol ialah Zulkifli bin Muhammad. ${ }^{20}$ 


\section{Penubuhan Persekutuan Melayu Mesir (PMM)}

Pada 5 Disember 1956, PPS secara rasmi telah ditukar nama kepada Persekutuan Melayu Mesir (PMM) atau dalam bahasa Arabnya al-Jam'iyyah al-Malayuwiyyah bi Misr. ${ }^{21}$ Yang Dipertua persatuan ketika itu ialah Muhammad Ghazali bin Abdul Wahid. ${ }^{22}$ Berdasarkan rekod surat-menyurat, sebelum pembinaan bangunan Rumah Melayu pejabat PMM terletak di alamat No. 10, Syari' Sharif Pasha al-Kabir, 'Abidin, Cairo. ${ }^{23}$ Kemudian pejabat PMM berpindah ke alamat Imaret Najmat el-Khalig, $4^{\text {th }}$ Floor, Shari' Port Said, Cairo. ${ }^{24}$

Penubuhan PMM bertujuan untuk mencapai tiga perkara. Pertama, untuk menyatupadukan pelajar dan orang Melayu yang tinggal di Mesir. Kedua, untuk mengurus dan membantu pelajar dan orang Melayu di Mesir terutamanya mereka yang mengalami masalah pengajian. Ketiga, berusaha untuk sentiasa mengadakan kegiatan-kegiatan kebudayaan, sosial dan sukan serta bekerjasama dengan pertubuhan yang ada di Mesir dalam mengadakan kegiatan tersebut. ${ }^{25}$ Ketiga-tiga matlamat penubuhan PMM tersebut dilihat sama dengan matlamat penubuhan PPS sebelum itu, cuma perbezaannya ialah lingkungan keanggotaan PMM lebih meluas. Ini kerana PPS hanya menerima keanggotaan pelajar dari Semenanjung Tanah Melayu sahaja, tetapi PMM turut menerima keanggotaan pelajar Melayu dari Singapura, Brunei, Sabah, Sarawak dan Selatan Thailand.

Walaupun dinyatakan secara jelas dalam Undang-Undang Tubuh PMM bahawa PMM ditubuhkan pada 5 Disember 1956, tetapi terdapat maklumat dalam sebuah buku terbitan PMRAM bertajuk Realiti Gelombang Aura Mahasiswa dan Hak Kita: ARMA yang menyatakan bahawa PMM telah ditubuhkan tiga tahun lebih awal iaitu pada tahun $1953 .{ }^{26}$ Ini dikuatkan lagi dengan rekod surat-menyurat PMM yang menunjukkan bahawa persatuan tersebut telahpun menggunakan nama dan logo PMM sejak tahun 1953 lagi. $^{27}$ Menurut buku tersebut, PPS telah bertukar nama kepada PMM pada tahun 1953 setelah keputusan tersebut dicapai dalam Mesyuarat Agong PPS pada penghujung tahun 1952. Keputusan tersebut dibuat setelah mengambil kira syarat keanggotaan persatuan yang bukan sahaja untuk pelajarpelajar dari Semenanjung Tanah Melayu, bahkan turut menerima keanggotaan pelajar-pelajar Melayu dari Sabah, Sarawak, Brunei dan Selatan Thailand. ${ }^{28}$

Selain itu, terdapat juga beberapa maklumat dan gambar yang menunjukkan kegiatankegiatan pelajar Melayu di bawah PMM sebelum tarikh 5 Disember 1956. Antara kegiatan tersebut ialah pada tahun 1954, dua orang wakil PMM telah dihantar ke Karachi, Pakistan untuk menghadiri Kongres Pemuda Islam. ${ }^{29}$ Pada bulan Februari tahun 1955 pula, PMM telah menghantar pasukan kawat ke Persidangan Afro-Asia yang pertama kali diadakan di Bandung, Indonesia untuk menyokong kemerdekaan Tanah Melayu. ${ }^{30}$ Pada tahun 1955 juga PMM telah menyewa sebuah pejabat tetap setelah sekian lama berpindah-randah. ${ }^{31}$

Ketika Gamal Abdul Nasser dipilih sebagai Presiden Mesir yang kedua pada bulan Jun 1956, PMM telah menghantar dua orang wakil bagi menemui beliau untuk menyampaikan ucapan tahniah serta menghadiahkan sepasang pakaian kebangsaan Melayu dan sebilah keris sebagai lambang perjuangan rakyat Tanah Melayu yang berusaha untuk mendapatkan kemerdekaan. ${ }^{32}$ Sewaktu pencerobohan tiga kuasa besar iaitu Israel, British dan Perancis ke atas Mesir untuk menguasai Terusan Suez pada bulan Oktober dan November tahun 1956, sekumpulan pelajar Melayu yang juga anggota-anggota PMM telah menyertai barisan sukarelawan. Mereka menyertai perbarisan kawat melalui Kaherah. ${ }^{33}$ Terdapat juga pelajar-pelajar Melayu yang menyertai program derma darah untuk simpanan Bank Darah di hospital. ${ }^{34}$ Pelajar-pelajar wanita Melayu turut sama mengambil peranan dengan menjahit pakaian-pakaian tentera di medan petempuran. Setelah peperangan tamat, Presiden Gamal telah menghantar dua telegram khas kepada PMM bagi menyampaikan ucapan terima kasih di atas khidmat dan sokongan persatuan tersebut dalam menentang pencerobohan tiga kuasa besar tersebut. ${ }^{35}$ 
Dalam akhbar Berita Harian bertarikh 18 Jun 1961, salah seorang mantan Yang Dipertua PMM ada menyatakan bahawa beliau terlibat sama dalam penggubalan UndangUndang Tubuh PMM yang dilakukan pada tahun $1953 .{ }^{36}$ Selain itu, salah seorang bekas anggota PMM yang bernama Ahmad Sobri Salamon ${ }^{37}$ dengan jelas menyatakan dalam sebuah buku autobiografinya bahawa PMM ditubuhkan pada tahun $1952 .{ }^{38}$ Kenyataan ini masih tidak bercanggah dengan maklumat dalam buku Realiti Gelombang Aura Mahasiswa dan Hak Kita: ARMA terbitan PMRAM yang menyatakan bahawa PMM ditubuhkan pada awal tahun 1953. Ini kerana maklumat dalam buku terbitan PMRAM tersebut juga menyatakan bahawa keputusan untuk mengubah nama persatuan daripada PPS kepada PMM telahpun diputuskan selepas Mesyuarat Agung PPS yang bersidang pada penghujung tahun 1952. Kenyataan daripada kedua-dua bekas anggota PMM tersebut menguatkan lagi bukti bahawa PMM telah ditubuhkan lebih awal daripada tahun 1956.

Berdasarkan maklumat-maklumat tersebut, dapat disimpulkan bahawa PMM telahpun ditubuhkan sejak tahun 1953 lagi. Walau bagaimanapun, PMM hanya didaftarkan secara rasmi sebagai sebuah persatuan dengan pihak pendaftar kerajaan Mesir pada 5 Disember 1956 sebagaimana yang termaktub dalam Undang-Undang Tubuh PMM. ${ }^{39}$ Walaupun begitu, skop masa kajian ini dimulakan pada tahun 1956 sebagai tahun PMM ditubuhkan mengikut sebagaimana yang termaktub dalam Undang-Undang Tubuh PMM.

\section{Struktur Organisasi}

PMM telah mengatur pembahagian badan, aturan-aturan kerja dan struktur organisasinya dalam satu himpunan Peraturan Kerja. Himpunan Peraturan Kerja tersebut terbahagi kepada lima bahagian Peraturan Kerja yang kali terakhir telah dikuatkuasakan pada 21 November 1962. ${ }^{40}$ Berdasarkan himpunan Peraturan Kerja ini, terdapat tiga badan terpenting dan tertinggi dalam organisasi PMM iaitu Badan Pengurus, Badan Perancang dan Lembaga Peraturan Kerja.

Badan Pengurus dianggotai oleh 11 orang barisan kepimpinan tertinggi PMM iaitu Yang Dipertua, Naib Yang Dipertua, Setiausaha Agung, Naib Setiausaha Agung, Bendahari dan enam orang lagi anggota PMM yang dipilih dan dilantik dalam Mesyuarat Agung PMM. ${ }^{41}$ Enam orang tersebut merupakan ketua-ketua bagi enam buah badan yang ditubuhkan di bawah PMM. Mereka ialah Ketua Badan Penerangan, Ketua Badan Pengetahuan, Ketua Badan Bahasa dan Pustaka, Ketua Badan Sukan dan Perkelahan, Ketua Badan Kebajikan dan Ketua Badan Kesenian dan Kebudayaan. Bagi jawatan Setiausaha Agung, ianya mempunyai jabatannya sendiri yang terdiri daripada Naib Setiausaha Agung sendiri dan beberapa orang anggota di bawahnya. ${ }^{42}$ Begitu juga jawatan Bendahari yang mempunyai jabatannya sendiri yang terdiri daripada seorang setiausaha, seorang ketua penjaga harta benda dan penolongnya serta beberapa orang anggota di bawahnya. ${ }^{43}$ Badan Pengurus adalah kuasa kedua di bawah Mesyuarat Agong yang boleh memberi kuasa kepada Yang Dipertua untuk menguatkuasakan Peraturan Kerja. ${ }^{44}$ Badan Pengurus dibantu oleh Badan Perancang dan Lembaga Peraturan Kerja dalam menggubal atau melaksanakan sesuatu peraturan.

Badan Perancang bertujuan untuk membantu Badan Pengurus dalam menyusun Peraturan Kerja, menyediakan rancangan-rancangan PMM dan memberi panduan kepada anggota-anggota PMM. ${ }^{45}$ Cogan kata Badan Perancang ialah "belajar sambil berkhidmat." Badan ini dianggotai oleh seorang ketua iaitu Naib Yang Dipertua PMM, Setiausaha, pengelola setiap bahagian dan anggota-anggota badan. Di bawah Badan Perancang terdapat tiga bahagian (komiti) terpenting iaitu Bahagian Fikiran dan Nasihat, Bahagian Kerja dan Penyiaran dan Bahagian Pemerhatian dan Panduan. ${ }^{46}$ Setiap bahagian diketuai oleh seorang Pengelola Bahagian dan masing-masing mempunyai tugas mereka sendiri. ${ }^{47}$

Badan Perancang merupakan sebuah badan yang dilihat penting kerana kejayaan sesuatu program amat bergantung pada perancangan yang teliti dan sempurna. Ini untuk 
memastikan supaya setiap program yang dijalankan di bawah nama persatuan dapat berjalan lancar dan tidak terpesong daripada matlamat utama persatuan.

Lembaga Peraturan Kerja pula adalah satu badan yang anggota-anggotanya dilantik oleh Badan Pengurus dan bertanggungjawab untuk menapis, meminda, menambah atau menyusun semula segala susunan Peraturan Kerja yang diutarakan oleh Badan Pengurus dan Badan Perancang. ${ }^{48}$ Walau bagaimanapun, Lembaga Peraturan Kerja tiada hak dalam menguatkuasakan sebarang Peraturan Kerja. ${ }^{49}$ Lembaga ini dianggotai oleh seorang ketua, setiausaha dan dua orang anggota. ${ }^{50}$

Peraturan merupakan sesuatu yang amat penting bagi sesebuah persatuan untuk mengawal tindak-tanduk setiap anggota dan memastikan persatuan tersebut sentiasa ditadbir dengan baik sesuai dengan matlamat persatuan. Lembaga Peraturan Kerja dilihat sebuah badan yang penting dalam PMM kerana badan inilah yang memastikan perjalanan persatuan tidak terkeluar dari landasan asal matlamat perjuangan PMM. Walau bagaimanapun, lembaga ini tidak diberi kuasa untuk menguatkuasakan sesuatu peraturan yang telah disusun. Ini juga dilihat penting bagi memastikan sesuatu peraturan itu bersih daripada sebarang unsur monopoli dan manipulasi pihak-pihak tertentu.

Badan-badan lain yang ditubuhkan di bawah PMM ialah Badan Penerangan, Badan Pengetahuan, Badan Bahasa dan Pustaka, Badan Sukan dan Perkelahan, Badan Kebajikan dan Badan Kesenian dan Kebudayaan. ${ }^{51}$ Kenam-enam orang ketua badan tersebut merupakan anggota Badan Pengurus. Ketua-ketua badan tersebut berhak memilih pembantu-pembantu mereka dalam kalangan anggota PMM dengan persetujuan daripada Badan Pengurus. ${ }^{52}$

Badan Penerangan adalah sebuah badan yang bertanggungjawab mengeluarkan berita dan penerangan kepada semua anggota PMM. Badan ini juga bertanggungjawab mengeluarkan dan menerbitkan majalah Warta PMM, iaitu lidah rasmi persatuan yang dikeluarkan dua kali setiap bulan. ${ }^{53}$ Badan Penerangan dianggotai oleh seorang ketua, Setiausaha, Pengelola Urusan Filem, wartawan, juru taip dan pembantu umum. ${ }^{54}$

Badan Penerangan dilihat sebagai jurucakap dan wakil rasmi PMM dalam menyampaikan sesuatu maklumat persatuan kepada umum. Badan ini memainkan peranan penting dalam memastikan setiap maklumat berkaitan persatuan yang hendak dihebahkan benar-benar sahih dan diakui. Bahkan badan ini juga bertindak sebagai duta kecil kerana sering melaporkan kepulangan anggota-anggota PMM yang telah berjaya menamatkan pengajian mereka di Mesir melalui akhbar-akhbar di tanah air. ${ }^{5.5}$

Badan Pengetahuan adalah badan yang bertanggungjawab mengendalikan kegiatankegiatan ilmiah. Badan Pengetahuan telah menubuhkan Keluarga Pidato dan Perbahasan di bawahnya yang bertujuan untuk melatih anggota-anggota PMM yang berminat untuk mengasah bakat mereka berucap di khalayak ramai dengan baik dan mampu mengeluarkan hujah-hujah dengan bijak dalam perdebatan. ${ }^{56}$ Selain itu, Badan Pengetahuan juga ada menubuhkan Bahagian Bahasa Asing yang diketuai oleh seorang Pengarah, Setiausaha, Ketua Bahasa Arab dan penolongnya dan Ketua Bahasa Inggeris dan penolongnya. ${ }^{57}$

Kewujudan Badan Pengetahuan dalam PMM dilihat telah menggalakkan pelajarpelajar Melayu terlibat dalam pelbagai kegiatan ilmiah sama ada dalam bentuk akademik mahupun kemahiran insaniah. Ini secara tidak langsung telah meningkatkan kefahaman mereka dalam pelajaran seterusnya memperoleh keputusan yang cemerlang dalam peperiksaan. Ini terbukti apabila dua orang anggota PMM pernah mendapat penghargaan daripada Presiden Mesir, Gamal Abdul Nasser pada tahun 1963 dan 1964 kerana berjaya memperoleh keputusan yang cemerlang dalam peperiksaan. Mereka berdua ialah Jaafar bin Hassan dan Muhamad bin Che Wook yang mendapat penghargaan tersebut dalam majlis sambutan Hari Ilmu Pengetahuan yang disambut setiap tahun di Kaherah. ${ }^{58}$

Badan Bahasa dan Pustaka pula pada asalnya merupakan sebahagian daripada Badan Pengetahuan. ${ }^{59}$ Badan Bahasa dan Pustaka dianggotai oleh seorang ketua, Setiausaha, 
Pengelola Taman Bacaan, Pengelola Bahagian Karangan dan Penterjemahan dan Pengelola Bahagian Persuratan dan Kesusasteraan. ${ }^{60}$ Badan Bahasa dan Pustaka juga ada menubuhkan Lembaga Istilah yang diketuai oleh seorang pengarah, seorang setiausaha dan beberapa orang anggota PMM yang dilantik di bawahnya. ${ }^{61}$ Lembaga ini ditugaskan untuk mengeluarkan artikel yang menterjemahkan istilah-istilah tertentu dalam Bahasa Arab ke dalam Bahasa Melayu.

Penubuhan Badan Dewan Bahasa dan Pustaka dalam PMM membuktikan bahawa PMM bersungguh-sungguh dalam memartabatkan Bahasa Melayu dalam kalangan anggotanya walaupun berada di perantauan. Badan yang dinamakan sempena nama Dewan Bahasa dan Pustaka (DBP) di tanah air ini juga menganjurkan majlis Bulan Bahasa Kebangsaan di Kaherah sebagaimana yang diadakan oleh DBP setiap tahun di tanah air. ${ }^{62}$ Penganjuran majlis tersebut bukan sahaja menggalakkan kegiatan ilmiah dalam kalangan anggota PMM, malah turut berperanan memperkenalkan Bahasa Melayu kepada rakyat asing di Kaherah.

Badan Kebajikan ditubuhkan untuk menguruskan hal ehwal kebajikan anggotaanggota PMM. Badan ini kebiasaannya akan menguruskan sebarang majlis sambutan dan perpisahan. Badan ini juga dilihat sering menguruskan setiap sambutan perayaan Aidilfitri dan Aidiladha. Pengurusan bayaran zakat fitrah anggota-anggota PMM dan urusan pengagihannya juga dikelolakan oleh Badan Kebajikan. ${ }^{63}$ Badan Kebajikan merupakan salah satu badan yang amat penting dalam PMM. Ini kerana salah satu matlamat utama penubuhan PMM ialah mengurus dan membantu pelajar Melayu sepanjang pengajian mereka di Mesir.

Badan Rehlah dan Sukan atau Badan Sukan dan Perkelahan merupakan sebuah badan yang ditubuhkan untuk merancang kegiatan-kegiatan sukan dan lawatan. Badan ini mempunyai tiga bahagian iaitu Bahagian Bola Sepak, Bahagian Perkelahan (Lawatan) dan Bahagian Ping Pong. Badan ini dianggotai oleh seorang ketua, setiausaha, pengelola dan penolong pengelola pada setiap bahagian. ${ }^{64}$ Pada 28 September 1962, Badan Sukan dan Perkelahan telah menubuhkan satu lagi bahagian iaitu pasukan Bola Tangkis (Badminton). ${ }^{65}$

Kewujudan Badan Rehlah dan Sukan dalam PMM menunjukkan bahawa PMM juga amat mementingkan kesihatan fizikal dan mental anggota-anggotanya. Selain itu, badan ini juga memainkan peranan yang besar dalam mengeratkan hubungan antara anggota PMM dengan persatuan-persatuan pelajar yang lain di Kaherah melalui penganjuran pelbagai perlawanan sukan yang bersifat antarabangsa. ${ }^{66}$ Lawatan yang kerap dianjurkan oleh badan ini juga menjadikan anggota PMM lebih mengenali dunia luar dan tidak menjadi seperti katak di bawah tempurung.

Badan Kesenian dan Kebudayaan pula ditubuhkan bagi memperkenalkan kesenian dan kebudayaan bangsa Melayu kepada rakyat Mesir dan negara-negara lain dengan mengadakan pelbagai persembahan dan pertunjukan kesenian dan kebudayaan Melayu pada waktu-waktu tertentu. Badan ini juga menjalankan kegiatan mempelajari seni budaya bangsa asing yang bersesuaian dengan jiwa masyarakat Melayu. ${ }^{67}$ Terdapat lima bahagian di bawah badan ini iaitu Bahagian Bunyi-Bunyian dan Muzik, Bahagian Nyanyian dan Tari Menari, Bahagian Lakonan dan Sandiwara, Bahagian Pencak Silat dan Bahagian Seni Lukis. ${ }^{68}$

Identiti bangsa merupakan sesuatu yang penting bagi setiap manusia dan itulah yang cuba ditekankan oleh PMM dengan penubuhan Badan Kesenian dan Kebudayaan. PMM memainkan peranan yang besar dalam memperkenalkan Persekutuan Tanah Melayu dan Malaysia kepada rakyat asing di Timur Tengah khususnya di Mesir dengan penganjuran pelbagai kegiatan kesenian dan kebudayaan Melayu di Kaherah. Bahkan, kegiatan tersebut mendapat liputan meluas di media massa dan elektronik di Kaherah. ${ }^{69}$

PMM juga pernah menubuhkan Badan Pemandu, Badan Pelajaran, Badan Politik ${ }^{70}$ dan Badan Wanita. ${ }^{71}$ Badan Pemandu merupakan sebuah badan yang bertindak sebagai penasihat kepada PMM dan membantu menggerakkan badan-badan dan anggota-anggota 
dalam melaksanakan sebarang tujuan dan kegiatan PMM. Bidang kuasanya hanyalah sebagai sebuah badan yang menasihatkan dan menyedarkan. ${ }^{72}$ Ini bermaksud badan ini memainkan peranan dalam memberi pandangan dan penerangan berkenaan sesuatu perkara yang melibatkan kegiatan-kegiatan PMM.

Badan ini telah menetapkan tiga cara mereka bekerja. Pertama, berusaha membentuk keperibadian yang tinggi dalam kalangan anggota PMM dengan mengadakan aktiviti perbincangan dan bertukar-tukar fikiran untuk mencari jalan penyelesaian terhadap masalah peribadi dan masyarakat. Kedua, mencegah kegiatan-kegiatan yang tidak bermoral dengan mengadakan aktiviti-aktiviti yang berfaedah. Ketiga, memberi buah fikiran dan nasihat kepada badan-badan yang akan menjalankan sebarang aktiviti. ${ }^{73}$ Badan ini dilihat lebih bersifat seperti badan dakwah dan badan penasihat. Antara tokoh yang pernah mengetuai badan ini ialah Shaykh Abdul Mohsein Salleh. ${ }^{74}$

Pada tahun 1963, PMM telah menubuhkan Keluarga Wanita. ${ }^{75}$ Pada 18 Februari 1962, Yang Dipertua PMM bersama Naib Setiausaha Agung PMM telah bertemu dengan Aishahtun binti Muhammad Fadhlullah Suhaimi, seorang pelajar wanita Melayu yang menuntut di Universiti Kaherah ketika itu untuk menjemputnya menghadiri perjumpaan pertama penubuhan Keluarga Wanita PMM. Perjumpaan tersebut telah diadakan pada 22 Februari di pejabat PMM. Namun begitu, pihak PMM telah membubarkan rancangan penubuhan Keluarga Wanita PMM disebabkan beberapa alasan yang tidak dinyatakan. ${ }^{76}$ Ini kemungkinan disebabkan oleh bilangan pelajar wanita yang kurang dari 10 orang. ${ }^{77}$

PMM juga ada menubuhkan Tabung Derma Pelajaran dan Jawatankuasa Urusan Persekolahan bagi membantu masalah kewangan dan pengajian anggota-anggotanya. ${ }^{78}$ Untuk memudahkan anggota-anggotanya menjelaskan pembayaran yuran bulanan, PMM juga telah melantik beberapa orang pengutip yuran dalam kalangan anggotanya yang akan mengutip yuran mengikut minggu dan kawasan penempatan pelajar Melayu di Kaherah. ${ }^{79}$ Panitia Rumah Melayu yang ditubuhkan sejak tahun 1932 masih dikekalkan. ${ }^{80}$

Pada tahun 1961, melalui cadangan daripada Badan Pengurus 1960 PMM telah menubuhkan Panitia Tetap Sasaran PMM. Panitia ini bermatlamat untuk menubuhkan sebuah persatuan bekas pelajar-pelajar Melayu Mesir di Persekutuan Tanah Melayu. ${ }^{81}$ Pada tahun 1962, PMM telah menubuhkan Panitia Menafsirkan Undang-Undang Tubuh PMM yang bertujuan untuk menghuraikan isi kandungan Undang-Undang Tubuh PMM. ${ }^{82}$ PMM juga pernah menubuhkan Panitia Menyemak Kembali Undang-Undang Tubuh PMM (PMKUTPMM) ${ }^{83}$ dan Jawatankuasa Penasihat kewangan PMM. ${ }^{84}$

Mana-mana anggota Badan Pengurus juga boleh memegang beberapa jawatan ketua jawatankuasa atau panitia yang lain yang ada di bawah PMM seperti Tabung Derma Pelajaran, Panitia Rumah Melayu dan Badan Perancang. Pada setiap awal tahun setelah Mesyuarat Agung melantik semua anggota Badan Pengurus, satu majlis Timbang-Terima akan diadakan bagi upacara penyerahan jawatan daripada Badan Pengurus lama kepada Badan Pengurus baharu. ${ }^{85}$

Penubuhan pelbagai badan dan jawatankuasa menunjukkan bahawa pentadbiran PMM amat sistemetik dan tersusun. Setiap satunya berfungsi sebagai anggota badan yang mempunyai tugas dan peranannya sendiri. Setiap badan di bawah PMM melaksanakan tugas dan peranan masing-masing dengan baik sekali. Oleh kerana itulah, era PMM merupakan kemuncak kegemilangan pelajar-pelajar Melayu Semenanjung, Singapura, Sabah, Sarawak, Brunei dan Selatan Thailand di Kaherah.

\section{Barisan Kepimpinan}

Persatuan yang cemerlang ditadbir oleh barisan kepimpinan yang cemerlang. Berkenaan barisan kepimpinan PMM atau kesebelasan anggota Badan Pengurus yang pernah dilantik dari tahun 1956 sehingga tahun 1964, kajian ini telah mengenal pasti mereka yang pernah 
menganggotainya sepanjang tempoh tersebut melalui rekod-rekod catatan dan tandatangan daripada dokumen dan sumber yang diperoleh. Jawatan Yang Dipertua PMM telah disandang oleh Muhammad Ghazali bin Abdul Wahid dari tahun penubuhan PMM iaitu pada tahun 1956 sehingga tahun 1958. ${ }^{86}$ Antara barisan anggota Badan Pengurus pada tahun 1958 yang dikenalpasti ialah Muhammad Kamil Suhaimi yang menjawat jawatan Naib Yang Dipertua, ${ }^{87}$ Wan Mokhtar Ahmad sebagai Setiausaha Agung ${ }^{88}$ dan Wan Ahmad Osman sebagai Ketua Badan Penerangan. ${ }^{89}$

Ketika era pentadbiran Muhammad Ghazali, PMM didapati kurang aktif dengan kegiatan-kegiatan yang bercorak sosial tetapi lebih banyak melaksanakan kegiatan-kegiatan yang bercorak politik. Ini kerana ketika itu Persekutuan Tanah Melayu baharu sahaja mencapai kemerdekaan dan PMM ketika itu banyak melaksanakan kegiatan yang memperkenalkan tanah air kepada masyarakat asing di Kaherah. PMM ketika itu juga banyak terlibat dengan kegiatan yang menyokong perjuangan negara-negara Afrika sekitar Mesir untuk mendapatkan kemerdekaan.

Wan Mokhtar bin Wan Ahmad kemudiannya dilantik menggantikan kedudukan Muhammad Ghazali Abdul Wahid sebagai Yang Dipertua PMM bermula dari tahun 1959 sehingga tahun 1961. ${ }^{90}$ Pada tahun 1959, Othman Salleh merupakan Setiausaha Agung PMM. Beliau digantikan pula oleh Abdul Kader Talip pada tahun 1960. ${ }^{91}$

Anggota-anggota Badan Pengurus pada tahun 1961 yang dikenalpasti pula ialah Ishak Mohd. Rejab sebagai Naib Yang Dipertua, ${ }^{92}$ Muhd. Zain bin Hj. Serudin sebagai Setiausaha Agung, ${ }^{93}$ Omar Ismail Ahmad sebagai Naib Setiausaha Agung, ${ }^{94}$ Zainuddin bin Abdul Rahman sebagai Bendahari, ${ }^{95}$ Abdul Halim sebagai Ketua Badan Pengetahuan, ${ }^{96}$ Hashim Ahmad Ali sebagai Ketua Badan Penerangan, ${ }^{97}$ Mahalli bin $\mathrm{Hj}$. Abdullah sebagai Ketua Badan Sukan dan Perkelahan, ${ }^{98}$ Mohd. Husain Ali sebagai Ketua Badan Kebajikan ${ }^{99}$ dan Abdul Aziz Murshidi sebagai Ketua Badan Kesenian dan Kebudayaan. ${ }^{100}$

Era pentadbiran Wan Mokhtar Ahmad sebagai Yang Dipertua PMM telah menyaksikan pelbagai kemajuan telah dicapai dalam kegiatan-kegiatan pelajar Melayu di Kaherah. Dalam tempoh tersebut, PMM telah mendapat sebidang tanah daripada Presiden Gamal untuk pembinaan sebuah bangunan asrama yang khusus untuk pelajar-pelajar Melayu di Kaherah. Usaha mendapatkan sebidang tanah dan pembinaan bangunan asrama tersebut akhirnya telah dapat direalisasikan ketika itu setelah hampir tiga dekad persatuan tersebut berusaha ke arah tersebut sejak zaman PPS lagi.

Pada era pentadbiran Wan Mokhtar juga perhubungan diplomatik antara kerajaan Persekutuan Tanah Melayu dan kerajaan UAR (Mesir) mula terjalin. Ini mula berlaku apabila Rombongan Muhibah dari tanah air dihantar ke Mesir bagi menguruskan pertukaran hak milik tanah bangunan asrama pelajar Melayu. Hasil daripada lawatan rombongan tersebut, wujudnya Kedutaan Persekutuan Tanah Melayu di Kaherah dengan perlantikan Datuk Ghazali bin Hj. Jawi sebagai Duta Besar pertama pada tahun 1960. Oleh itu, dapatlah dinyatakan bahawa PMM berperanan sebagai tali penyambung antara kedua-dua buah negara umat Islam itu.

Kepimpinan PMM ketika itu juga terbukti kuat apabila berjaya mengatasi konflik dalaman yang hampir menyebabkan perpecahan dalam kalangan anggota PMM. Ketegasan dan kewibawaan Wan Mokhtar selaku Yang Dipertua PMM menyelesaikan konflik tersebut turut mendapat pujian daripada Timbalan Perdana Menteri di tanah air ketika itu, Tun Abdul Razak Hussein.

Pada tahun 1962, Abdul Kader bin Talip telah dilantik menjawat jawatan Yang Dipertua PMM menggantikan Wan Mokhtar Ahmad sementara Naib Yang Dipertuanya ialah Abdul Mohsein Salleh. Jawatan Setiausaha Agung disandang oleh Abu Bakar bin $\mathrm{Hj}$. Mohammad dan Naib Setiausaha Agung ialah Muhammad Taib Hassan. ${ }^{101}$ Jawatan Bendahari pula masih disandang oleh Zainuddin bin Abdul Rahman. Keenam-enam ketua 
badan pada tahun tersebut ialah $\mathrm{Hj}$. Ahmad bin $\mathrm{Hj}$. Saad sebagai Ketua Badan Pengetahuan, Muhd. Zain bin Hj. Serudin sebagai Ketua Badan Penerangan, Muhd. Ali Harun ${ }^{102}$ sebagai Ketua Badan Kebajikan, Hasbullah bin Abdul Razak sebagai Ketua Badan Bahasa dan Pustaka, Jaiz Anwar ${ }^{103}$ sebagai Ketua Badan Kesenian dan Kebudayaan, dan Abu Bakar Kassim sebagai Ketua Badan Sukan dan Perkelahan. ${ }^{104}$

PMM di bawah pentadbiran Abdul Kader Talip didapati banyak melaksanakan kegiatan yang berunsur sosial dan politik. Ini kerana pada tahun itu PMM mula menghasilkan majalah Warta PMM sebagai lidah rasmi persatuan. Majalah tersebut masih lagi diterbitkan dan menjadi lidah rasmi PMRAM sehingga kini. Majalah tersebut melaporkan segala kegiatan PMM dan pelajar-pelajar Melayu di Kaherah.

Jawatan Yang Dipertua PMM pada tahun 1963 kemudiannya telah disandang oleh Abu Bakar bin Hj. Mohammad sementara Ishak bin Muhd. Rejab ialah Naib Yang Dipertuanya. Setiausaha Agung pada tahun tersebut ialah Muhd. Ali Harun dan Naib Setiausaha Agung ialah Abdul Aziz Murshidi. Abdul Aziz Murshidi kemudiannya telah meletak jawatan dan Muhammad Taib Hassan telah menggantikan tempatnya. Omar Othman pula telah menjawat jawatan Bendahari. Muhd. Zain Serudin, Hasbullah bin Abdul Razak, Abu Bakar Kassim dan Jaiz Anwar masing-masing masih dikekalkan jawatan mereka yang disandang pada tahun sebelumnya iaitu sebagai Ketua Badan Penerangan, Ketua Badan Bahasa dan Pustaka, Ketua Badan Sukan dan Perkelahan dan Ketua Badan Kesenian dan Kebudayaan. Ketua Badan Pengetahuan telah disandang oleh Abdul Halim Zain dan $\mathrm{Hj}$. Ahmad bin Hj. Saad pula telah menyandang jawatan sebagai Ketua Badan Kebajikan. ${ }^{105}$

Era PMM di bawah pentadbiran Abu Bakar Hj. Muhammad ialah tahun pembentukan Persekutuan Malaysia di tanah air dan bangunan asrama di Kaherah telah siap dibina sepenuhnya. Oleh itu, pelbagai kegiatan yang bercorak sosial telah dilaksanakan oleh PMM ketika itu terutamanya kegiatan kebudayaan bagi memperkenalkan Malaysia kepada masyarakat asing di Kaherah.

Bagi tahun 1964, jawatan Yang Dipertua PMM telah disandang oleh Umar Ismail ${ }^{106}$ manakala Muhammad Taib Hassan merupakan Naib Yang Dipertuanya. Jawatan Setiausaha Agung pada tahun tersebut disandang oleh Ahmad Awang ${ }^{107}$ dan beliau dibantu oleh Ismail Abdul Halim sebagai Naib Setiausaha Agung. Jawatan Bendahari pula dipegang oleh Othman Ishak. ${ }^{108}$ Untuk jawatan ketua-ketua badan yang lain pula, Fadzil Mohd. Noor ${ }^{109}$ merupakan Ketua Badan Penerangan, Abdul Halim Zain sebagai Ketua Badan Pengetahuan, $\mathrm{Hj}$. Ahmad Saad sebagai Ketua Badan Bahasa dan Pustaka, Yahya Othman ${ }^{110}$ sebagai Ketua Badan Kebajikan, Abdul Halim Othman sebagai Ketua Badan Sukan dan Perkelahan dan Ismail Ibrahim sebagai Ketua Badan Kesenian dan Kebudayaan. ${ }^{111}$

Ramai tokoh penting politik dalam parti Persatuan Islam Semalaysia (PAS) dilihat mula terlibat dalam kepimpinan tertinggi PMM ketika era pentadbiran Umar Ismail. Nama tokoh-tokoh penting PAS seperti Fadzil Mohd. Noor, Ahmad Awang dan Yahya Othman dilihat mulai memimpin persatuan pada tahun itu. PMM ketika era ini dilihat semakin berkembang maju dengan pelbagai kegiatan yang bercorak sosial dilaksanakan.

Dalam soal perlantikan anggota-anggota Badan Pengurus ini, pernah terjadi satu konflik yang menyebabkan perpecahan dalam PMM. Konflik tersebut bermula pada awal tahun 1961 apabila Badan Pengurus tahun 1961 telah melantik tiga orang pelajar Melayu yang bukan warganegara Persekutuan Tanah Melayu sebagai anggota Badan Pengurus pada tahun tersebut. Mereka ialah Mohd. Zain Serudin dari Brunei yang dilantik sebagai Setiausaha Agung, Mahalli Abdullah yang juga dari Brunei yang dilantik sebagai Ketua Badan Sukan dan Perkelahan, dan Abdul Aziz Murshidi dari Singapura yang dilantik sebagai Ketua Badan Kesenian dan Kebudayaan. ${ }^{112}$

Perlantikan tersebut tidak dipersetujui oleh sekumpulan 14 orang anggota PMM yang diketuai oleh Mohd. Noor Abdul Wahab dengan alasan bahawa mereka bertiga bukan 
warganegara Persekutuan Tanah Melayu dan sepatutnya tidak layak menjadi anggota PMM apatah lagi memegang mana-mana jawatan dalam PMM. Konflik tersebut telah menyebabkan anggota PMM berpecah kepada dua golongan iaitu barisan Badan Pengurus yang diketuai oleh Wan Mokhtar Ahmad yang juga Yang Dipertua PMM ketika itu dan kumpulan penentang yang diketuai oleh Mohd. Noor Abdul Wahab. Terdapat tujuh orang anggota PMM menjadi orang tengah untuk cuba mendamaikan dua kumpulan tersebut. Konflik tersebut diburukkan lagi apabila salah seorang anggota penentang tersebut dilucutkan keanggotaannya. ${ }^{113}$ Kronologi konflik itu juga turut dilaporkan di tanah air dalam akhbar Berita Harian apabila ada dalam kalangan anggota- anggota PMM sama ada yang menyokong Badan Pengurus atau menyokong kumpulan penentang tersebut mengirim surat laporan dan pandangan masing-masing berkenaan krisis tersebut kepada pihak Berita Harian. ${ }^{114}$

Kumpulan penentang tersebut telah menuntut mesyuarat tergempar tetapi gagal. Akhirnya mereka mengadu masalah tersebut kepada pihak kedutaan Persekutuan Tanah Melayu di Kaherah dan pihak kedutaan telah menyebelahi mereka. Walaupun telah dijelaskan bahawa Undang-Undang Tubuh PMM juga menerima keanggotaan pelajar Melayu yang bukan warganegara Persekutuan Tanah Melayu, tetapi pihak kedutaan tetap bertegas menyatakan PMM hanyalah eksklusif untuk pelajar warganegara Persekutuan Tanah Melayu sahaja dan mereka mahu keanggotaan ketiga-tiga pelajar Melayu dari Brunei dan Singapura itu digugurkan. Ketegasan Wan Mokhtar Ahmad selaku Yang Dipertua PMM ketika itu yang menolak permintaan tersebut telah menyebabkan hubungan antara kedua-dua pihak menjadi tegang sehingga pihak kedutaan menarik kembali elaun bulanan yang diberikan kepada PMM. Ketegangan hubungan antara kedua-dua pihak tersebut diketahui oleh pihak kerajaan Persekutuan Tanah Melayu. Tun Abdul Razak yang ketika itu merupakan Timbalan Perdana Menteri telah mengutus surat kepada pihak PMM memuji sikap persatuan tersebut. Akhirnya selepas Wan Mokhtar Ahmad mengirim surat menjelaskan perkara sebenar kepada Tun Abdul Razak, hubungan antara PMM dan pihak kedutaan di Kaherah beransur pulih. ${ }^{115}$

Berkenaan rekod bilangan anggota-anggota PMM yang berdaftar, pada tahun 1957, PMM mempunyai 114 orang anggota. ${ }^{116}$ Pada tahun 1963, bilangan anggotanya telah bertambah kepada 203 orang. Daripada bilangan tersebut hanya enam orang sahaja anggotanya adalah wanita. ${ }^{117}$ Majalah Warta PMM sering melaporkan anggota-anggota baharu yang diterima permohonan keanggotaan mereka dan mereka yang pulang ke tanah air setelah tamat pengajian.

\section{Undang-Undang Tubuh PMM}

Secara umumnya Undang-Undang Tubuh PMM terbahagi kepada lima bab dan mengandungi 40 fasal. Bab Pertama ialah berkenaan nama markas dan tujuan penubuhan PMM. Di dalamnya mengandungi Fasal Satu sehingga Fasal Tiga. Bab Kedua berkenaan kewangan persekutuan dan di dalamnya terkandung Fasal Empat sehingga Fasal 12. Bab Ketiga berkenaan keanggotaan yang mengandungi Fasal 13 sehingga Fasal 19. Bab Keempat pula berkenaan segala peraturan lembaga atau badan yang terbentuk di bawah PMM. Bab ini mengandungi Fasal 20 sehingga Fasal 38. Bab Kelima iaitu bab yang terakhir ialah berkenaan pembubaran persatuan yang mengandungi Fasal 39 dan Fasal 40.

Undang-Undang Tubuh PMM bukanlah hanya bersifat tulisan di atas kertas sahaja, tetapi PMM telah melaksanakan pelbagai program supaya undang-undang tubuh tersebut sentiasa dipatuhi dan tidak ditafsir dengan cara yang salah. Tambahan pula, semasa konflik perlantikan Badan Pengurus pada tahun 1961, Undang-Undang Tubuh ini terutamanya berkenaan syarat keanggotaan persatuan telah disalah tafsir sehingga menyebabkan pertikaian dalam kalangan anggota-anggota PMM. 
Untuk memberi kefahaman yang jelas tentang Undang-Undang Tubuh PMM kepada semua anggotanya, PMM telah mengatur satu program Malam Perbincangan Perlembagaan pada 6 Julai 1961. Tujuan program tersebut ialah untuk menerangkan kepada semua anggota PMM berkenaan empat perkara penting dalam Undang-Undang Tubuh PMM. Empat perkara tersebut ialah berkenaan nama dan tujuan perlembagaan, jenis-jenis keanggotaan, syarat dan peranan setiap anggota PMM, peranan anggota wanita dan tugas Badan Pengurus. Setiap perkara tersebut telah dilantik seorang anggota PMM yang berpengalaman untuk menerangkannya seperti Shaykh Abdul Mohsein Salleh diberi tanggungjawab untuk menerangkan perkara mengenai tugas-tugas Badan Pengurus. ${ }^{119}$

Dalam Mesyuarat Agung PMM tahun 1960, PMM telah menubuhkan Panitia Menyemak Kembali Undang-Undang Tubuh PMM bagi mengenal pasti perkara-perkara di dalam Undang-Undang Tubuh PMM yang perlu diberi penafsiran dan penerangan yang terperinci kepada semua anggota PMM. Antara mereka yang dilantik menganggotai panitia tersebut ialah Omar Ismail Ahmad dan Shaykh Abdul Mohsein Salleh. ${ }^{120}$ Hasil penyemakan Undang-Undang PMM yang dilakukan oleh panitia tersebut juga telah mendapat kelulusan daripada Kementerian Kemasyarakatan UAR (Wizarah al-Ijtima'iyyah). ${ }^{121}$ Kelulusan daripada Kementerian Kemasyarakatan UAR membuktikan bahawa Undang-Undang Tubuh PMM juga diiktiraf oleh kerajaan Mesir.

Dalam Mesyuarat Agung PMM tahun 1961 pula, Badan Pengurus tahun 1961 telah memberi tanggungjawab kepada Badan Pengurus baharu untuk melakukan pentafsiran kepada Undang-Undang Tubuh yang telah disemak. ${ }^{122}$ Oleh itu, dalam mesyuarat Badan Pengurus tahun 1962 yang bersidang pada 15 Mac 1962, keputusan mesyuarat telah melantik 15 orang menganggotai Panitia Mentafsir Undang-Undang Tubuh PMM. ${ }^{123}$ Walau bagaimanapun, pada bulan Ogos 1962, semua anggota panitia telah meletak jawatan secara serentak tanpa dinyatakan sebab perbuatan mereka. ${ }^{124}$ Oleh itu, Badan Pengurus telah menyerahkan tugas panitia tersebut kepada Badan Perancang.

Pada 20 Disember 1962, Badan Perancang PMM telah mengeluarkan Penyata Badan Perancang Mengenai Penafsiran Undang-Undang Tubuh PMM. Sebanyak 14 perkara melibatkan 10 Fasal telah ditafsir dan diperincikan. Penyata tersebut telah diluluskan dalam mesyuarat Badan Pengurus yang bersidang pada 18 Disember 1962. Satu sidang khas dicadangkan oleh Badan Perancang untuk mengumpulkan semua anggota PMM untuk diberi penerangan tentang penyata tersebut. ${ }^{125}$

Daripada program Malam Perbincangan Perlembangaan sehingga penubuhan dua panitia untuk menyemak dan mentafsir Undang-Undang Tubuh yang dilakukan oleh PMM, jelas menunjukkan bahawa PMM begitu bersungguh-sungguh berusaha untuk memberi kefahaman kepada semua anggotanya tentang matlamat penubuhan persatuan dan tanggungjawab setiap anggotanya. Ini perlu dilakukan agar pengurusan dan pentadbiran persatuan dapat dijalankan dengan cemerlang. Ini juga bagi mengelakkan masalah dan pertikaian dalaman persatuan pada masa akan datang daripada kembali berlaku sepertimana yang pernah berlaku dalam PMM tentang keanggotaan pada tahun 1961.

\section{Kesimpulan}

PMM yang ditubuhkan seawal tahun 1953 merupakan kesinambungan daripada PPS yang ditubuhkan seawal tahun 1930 lagi. Walaupun terdapat sumber dan kajian lepas yang menyatakan bahawa PPS ditubuhkan pada tahun 1932, tetapi sumber daripada rekod Arkib Negara dan pihak PMRAM sendiri menyatakan bahawa PPS ditubuhkan dua tahun lebih awal, iaitu pada tahun 1930. Begitu juga tentang tahun penubuhan PMM, walaupun dinyatakan dalam Undang-Undang Tubuh PMM bahawa PMM ditubuhkan pada 5 Disember 1956, tetapi terdapat beberapa penemuan rekod dan bukti menunjukkan bahawa PMM telahpun wujud lebih awal daripada tahun tersebut, iaitu seawal tahun 1953 lagi. 
Artikel ini memberi gambaran secara am mengenai badan-badan yang dibentuk di bawah PMM seperti Badan Pemandu, Badan Pengetahuan, Badan Kesenian dan Kebudayaan, Badan Bahasa dan Pustaka dan banyak lagi. Badan-badan inilah yang bertanggungjawab menggerakkan PMM menerusi pelbagai kegiatan sosiopolitik. Sementara Badan Pengurus dan Badan Perancang merupakan dua badan utama yang memandu hala tuju PMM. Begitu juga penubuhan dan kegiatan pelbagai jawatankuasa kebajikan yang ditubuhkan di bawah PMM seperti Badan Kebajikan, Panitia Rumah Melayu, Tabung Derma Pelajaran dan Urusan Persekolahan. Ini menunjukkan PMM begitu menitikberatkan kebajikan semua anggotanya. PMM juga dilihat sentiasa berusaha untuk mencapai objektifnya. Ini dibuktikan dengan penubuhan Panitia Sasaran PMM.

Setiap kejayaan sesuatu persatuan itu bergantung pada terasnya iaitu peraturan di dalamnya dan kepatuhan anggota-anggotanya dalam melaksanakan peraturan tersebut. Kita dapat melihat bagaimana PMM menyusun peraturan kerja dan undang-undang tubuhnya yang mempunyai 40 Fasal. Bahkan mereka sentiasa memperhalusi Undang-Undang Tubuh supaya setiap anggota mendapat kefahaman yang betul dan peraturannya sesuai mengikut masa dan situasi. Ini dapat dilihat dengan penubuhan Panitia Menafsirkan Undang-Undang Tubuh PMM dan Panitia Menyemak Kembali Undang-Undang Tubuh PMM.

Kepatuhan kepada peraturan kerja dan undang-undang tubuh menjadikan PMM mempunyai organisasi yang teratur dan sistematik dan setiap pihak menjalankan peranan masing-masing dengan baik. Sikap barisan pimpinan tertinggi PMM yang berpendirian tegas berpegang pada undang-undang tubuhnya bukan sahaja berjaya menyelesaikan krisis keanggotaan yang pernah melanda PMM pada tahun 1961, bahkan mereka mendapat pujian daripada Tun Abdul Razak sendiri, Timbalan Perdana Menteri Persekutuan Tanah Melayu ketika itu. Barisan kepimpinan PMM yang berwibawa dan pengurusan organisasi yang cemerlang telah menjadikan era PMM sebagai kemuncak zaman kegemilangan pelajarpelajar Tanah Melayu, Singapura, Brunei dan Selatan Thailand di Kaherah.

\section{Nota}

${ }^{1}$ Md. Sidin Ahmad Ishak \& Mohammad Redzuan Othman, The Malays in The Middle East, Kuala Lumpur: University of Malaya Press, 2000, hlm. 57 (nota hujung no. 29). Gambar barisan kepimpinan PPS ini juga pernah dipaparkan dalam Majallah Guru, Jun 1933, Bil. 11, hlm muka hadapan dan halaman terakhir majalah. Dalam majalah yang sama juga ada disiarkan mengenai upacara sambutan ulang tahun PPS yang pertama bersama sambutan Hari Raya Aidiladha yang disambut pada bulan April 1933. Mereka yang memegang jawatan sebagai Yang Dipertua PPS dan PMM daripada tahun 1930 sehingga tahun 1966 diberi gelaran 'Tuan' di hadapan nama mereka kecuali jika nama mereka diawali dengan 'Tengku' atau 'Wan'. Lihat Lampiran 1.

${ }^{2}$ Realiti Gelombang Aura Mahasiswa dan Hak Kita: “ARMA”, Kaherah: Urusetia Penerangan Umum, Badan Penerangan dan Penerbitan PMRAM, 2011, hlm. 3-4. Persekutuan Putera-Putera Semenanjung (PPS) adalah nama asal bagi Persekutuan Melayu Republik Arab Mesir (PMRAM). Tarikh penubuhan PPS dinyatakan secara jelas dalam Arkib Negara Malaysia, Hari Ini Dalam Sejarah, Siaran 11 April 1981/1982. Dalam rekod Arkib Negara koleksi peribadi Amin Nordin bin Lebai Jemain, terdapat sekeping gambar barisan kepimpinan PPS pada tahun 1930/1932. Lihat SP 49, Gambar Persatuan Penuntut-Penuntut Melayu di Kaherah Pada Tahun 1930/1932.

${ }^{3}$ Lihat Lampiran 2.

${ }^{4}$ Lihat Lampiran 1.

${ }^{5}$ Nama penuh beliau ialah Amin Nordin @ Nuruddin bin Lebai Jemain yang lahir sekitar tahun 1904 di Kuala Kangsar, tetapi beliau membesar di Tanjung Rambutan, Perak. Beliau mendapat pendidikan awal di Sekolah Melayu Tanjung Melayu dan Sekolah Inggeris Anderson di Ipoh. Beliau berkahwin pada tahun 1922 dalam usia 18 tahun. Beliau kemudiannya menuntut di Madrasah al-Mashoor di Pulau Pinang dari tahun 1924 sehingga tahun 1927. Pada tahun 1927, beliau telah melanjutkan pengajian ke Mesir dan di sana beliau telah dilantik sebagai Yang Dipertua PPS yang pertama pada tahun 1930. Pada tahun 1932, setelah tamat pengajian di Mesir, 
beliau telah pulang ke tanah air. Pada tahun 1938, beliau turut sama menubuhkan Kesatuan Melayu Muda (KMM) di Ipoh. Disebabkan beliau aktif dengan kegiatan politik yang beraliran kiri ketika itu, beliau pernah dipenjarakan di Penjara Pudu di Kuala Lumpur dan kemudiannya dipindahkan ke Penjara Changi di Singapura. Semasa penaklukan Jepun, beliau telah dibebaskan dari penjara dan dihantar pulang ke Perak. Beliau juga pernah dilantik oleh pihak Jepun sebagai Ahli Majlis Negeri. Selepas pengunduran tentera Jepun dari Malaya, beliau telah ditahan oleh pihak komunis Bintang Tiga kerana disyaki bersubahat dengan pihak Jepun. Walau bagaimanapun, beliau berjaya melepaskan diri daripada tahanan tersebut. Selepas pihak British berjaya mengambil alih semula pemerintahan Malaya daripada pihak komunis, beliau dipenjarakan pula oleh pihak British di Penjara Batu Gajah selama dua bulan. Beliau kemudiannya memasuki ketenteraan sebagai tukang kayu di Taiping selama enam bulan sebelum bekerja sebagai arkitek di Ipoh. Bermula pada tahun 1948 sehingga tahun 1960, beliau bekerja dengan Keretapi Tanah Melayu (KTM). Lihat rekod Arkib Negara Kuala Lumpur, SP 49, Amin Nordin bin Lebai Jemain.

${ }^{6}$ Shaykh Fadhlullah Suhaimi (1886-1964) merupakan seorang tokoh ulama dan pendidik yang berasal dari Singapura. Beliau yang juga merupakan pelajar Melayu lulusan Universiti al-Azhar pada tahun 1911-1914 pernah menubuhkan sebuah syarikat percetakan Matba'ah al-Ittihadiyyah di Kaherah pada tahun 1914. Sekembalinya Shaykh Fadhlullah ke Singapura pada tahun 1914, beliau berkhidmat sebagai guru dan terlibat dengan pengasasan pelbagai institusi pendidikan di Tanah Melayu, Singapura dan Indonesia. Beliau pernah berkhidmat sebagai guru di Madrasah al-Sagof al-Arabiyyah di Singapura (1914), Guru Besar Kuliyyah al-Attas di Johor Bahru, Johor (1927), Guru Besar dan Nazir Maahad al-Muhammadi di Kota Bharu, Kelantan (19421945) dan Pengetua Kuliyyah al-Lughah wa al-Din di Pekan, Pahang (1956). Shaykh Fadhlullah juga terlibat dengan pengasasan pelbagai institusi pendidikan di ketiga-tiga negara tersebut. Antaranya ialah pengasasan Madrasah al-Ma'arif di Wosonobo, Jawa Timur (1918), Madrasah al-Hidayah di Garut, Jawa Barat, Madrasah al-Ma'arif al-Islamiyyah di Singapura (1936), Kuliyyah al-Firdaus di Singapura (1938), Madrasah al-Ridwan di Singapura (1940), Madrasah Na'im li al-Banat di Kota Bharu, Kelantan (1942), Madrasah al-Kauthar di Pasir Puteh, Kelantan, dan Kolej Islam Malaya di Klang (1955). Selain pernah dilantik sebagai Inspektor Pengajaran Agama di Sekolah Melayu Singapura, Shaykh Fadhlullah juga terlibat secara langsung dalam penubuhan beberapa buah persatuan guru dan pelajar agama di Singapura seperti Persatuan Guru Agama Singapura (PERGAS) dan Persatuan Pelajar-Pelajar Dewasa Singapura (PERDAUS). Lihat: Abu Hanifah Haris \& Mohammad Redzuan Othman, "Sumbangan Lepasan Mesir dalam Bidang Pendidikan dan Penulisan di Tanah Melayu dan Indonesia, 1920-an Hingga 1970-an," dalam International Journal of West Asian Studies, Vol. 5, No. 1, 2013, hlm. 8-9.

${ }^{7}$ Shaykh Hj. Hussin bin Hj. Abbas (1903-1966) merupakan mantan Kadi Besar Negeri Selangor dan juga pernah menjadi Hakim di Mahkamah Syariah Klang. Beliau mendapat pendidikan awal di sekolah agama di Bukit Mertajam, Pulau Pinang sebelum melanjutkan pengajian ke Universiti al-Azhar di Kaherah, Mesir pada tahun 1924. Beliau dilantik memegang jawatan sebagai Kadi Besar negeri Selangor pada tahun 1947 dan bersara pada tahun 1960. Walau bagaimanapun, beliau dilantik semula menjawat jawatan tersebut sehingga beliau meninggal dunia pada bulan Oktober 1969. Lihat: "Kadhi Besar Selangor Meninggal Dunia," Berita Harian, 25 Oktober 1969, hlm. 2.

${ }^{8}$ Shaykh Ahmad Ataullah Suhaimi berasal dari Jawa tetapi menetap di Singapura. Beliau yang juga merupakan adik kepada Shaykh Fadhlullah Suhaimi melanjutkan pengajian ke Universiti al-Azhar pada tahun 1918 dan pernah dilantik memegang jawatan sebagai Ahli Jawatankuasa Tertinggi Persatuan Pelajar-Pelajar Jawi Universiti al-Azhar pada tahun 1927. Lihat Seruan Azhar, Bil. 16, Januari 1927, hlm. 318.

${ }^{9}$ Shaykh Mohammad Saman merupakan bekas Ketua 2 Kadi Negeri Perlis.

${ }^{10}$ Shaykh Abdul Halim bin Othman (1910- 1997) merupakan Tokoh Guru Negeri Kedah pada tahun 1983. Beliau dilahirkan di Tanjung Pauh, Jitra, Kedah dan mendapat pendidikan awal di Sekolah Rendah Jitra dan Madrasah Hj. Wan Sulaiman bin Wan Sidik di Limbong Kapal, Alor Setar, Kedah. Beliau melanjutkan pengajian ke Universiti al-Azhar, Mesir pada tahun 1927 dan pulang ke tanah air setelah berjaya memperoleh Ijazah Sarjana Muda pada tahun 1937. Sekembalinya beliau ke tanah air, beliau dilantik sebagai Pengetua Maktab Mahmud yang pertama (1937-1954) sebelum dilantik sebagai Pendaftar Sekolah-Sekolah Agama Negeri Kedah (1954-1966). Pada tahun 1966, beliau dilantik pula menjawat jawatan Yang Dipertua Majlis Hal Ehwal Agama Islam Negeri Kedah dan terus menjawat jawatan tersebut sehingga tahun 1971 walaupun setelah bersara pada tahun 1969. Beliau juga merupakan Pengerusi Majlis Jawatankuasa Fatwa Kebangsaan yang kedua (1991-1992). Lihat: Bahagian Senarai Pengerusi-Pengerusi JKF, dalam Laman Web Rasmi Fatwa Malaysia, Jabatan Kebajikan Kemajuan Islam Malaysia (JAKIM), http://www.e-fatwa.gov.my/biografipengerusi/datosheikh-abdul-halim-bin-osman.

${ }^{11}$ Abdul Jalil Hassan (1914 - 1990) merupakan tokoh ulama di Malaysia terutamanya di negeri Johor. Beliau yang berasal dari Kg. Serom, Muar, Johor, mendapat pendidikan awal di sekolah Melayu di Johor dan Royal English School di Singapura sebelum melanjutkan pengajian ke Mesir pada tahun 1930. Ketika masih dalam pengajian di Universiti al-Azhar, beliau dilantik sebagai Yang Dipertua PPS yang keenam pada tahun 1944 
sehingga tahun 1946. Sekembalinya beliau ke tanah air selepas Perang Dunia Kedua, beliau dilantik sebagai Pemangku Mufti negeri Johor. Pada tahun 1962, beliau dilantik sebagai Mufti Besar Johor sehinggalah beliau meletak jawatan pada tahun 1964. Beliau pernah menjadi pengetua Kolej Islam Malaya di Klang. Apabila kolej tersebut dijadikan Fakulti Pengajian Islam Universiti Kebangsaan Malaysia pada tahun 1970, beliau telah dilantik sebagai dekan fakulti tersebut dan dianugerahkan gelaran Profesor. Beliau yang juga tokoh penting dalam Pertubuhan Kebajikan Islam Malaysia (PERKIM) pernah dilantik sebagai Pengerusi Majlis Fatwa Kebangsaan yang pertama pada tahun 1970-1990. Lihat Suara PERKIM, Tahun 12, Keluaran 2, Kuala Lumpur: PERKIM, hlm. 2-3.

${ }^{12}$ Muhammad Nasir Jauhari merupakan pelajar Melayu yang berasal dari Johor. Beliau pernah dilantik sebagai Ahli Jawatankuasa Tertinggi Persatuan Pelajar-Pelajar Jawi Universiti al-Azhar pada tahun 1927 dan 1928. Lihat Seruan Azhar, Bil. 16, Januari 1927, hlm. 318 dan Seruan Azhar, Bil. 27, Disember 1927, hlm. 564.

${ }^{13}$ Tuan Hj. Ismail Hj. Hamzah (m. 1954) merupakan mantan Mufti Besar Perak yang kedua pada tahun 1941 1954. Beliau juga pernah memegang jawatan sebagai Yang Dipertua PPS yang ketiga pada tahun 1934-1935 sewaktu dalam pengajian di Universiti al-Azhar, Mesir.

${ }^{14}$ Salleh Othman merupakan bekas Setiausaha Tetap dan mantan Ketua Pegawai Bahagian Agama di Kementerian Pelajaran Malaysia.

${ }^{15}$ Shaykh Hamzah bin Hj. Mu'ti (1913) yang berasal dari Manong, Kuala Kangsar, Perak merupakan pelajar Melayu lulusan Universiti al-Azhar, Mesir yang pernah dilantik oleh Jabatan Agama Islam Negeri Perak sebagai Pegawai Penerangan Agama Islam Negeri pada tahun 1964. Lihat: "Bertanggong Jawab Mengatasi AjaranAjaran yang Salah,” Berita Harian, 15 Januari 1964, hlm. 9. Beliau juga merupakan tokoh penting dalam Persatuan Melayu Perak.

${ }^{16}$ Surat Ringkas bagi Timbangan Majlis Mesyuarat Raja-Raja, Penuntut-Penuntut Melayu di Kaherah, dalam SUK Tr. 617/1948. Sebelum penubuhan PPS lagi, pengurusan pelajar-pelajar dari negeri Johor di Mesir dilihat lebih terjaga dan tersusun berbanding pengurusan pelajar-pelajar dari negeri-negeri Semenanjung Tanah Melayu yang lain di Mesir. Buktinya, negeri Johor merupakan antara negeri Semenanjung Tanah Melayu yang terawal memberi biasiswa kepada pelajarnya di luar negara. Pelajar-pelajar Johor di Mesir juga sudah ada sebuah asrama mereka sendiri yang dikenali sebagai Rumah Johor.

${ }^{17}$ Ibid.

${ }^{18}$ Md. Sidin Ahmad Ishak \& Mohammad Redzuan Othman, The Malays in The Middle East, hlm. 50-51.

${ }^{19}$ Ibid.

${ }^{20}$ Zulkifli bin Muhammad (1927-1964) yang berasal dari Perak merupakan presiden PPS dari tahun 1949 sehingga tahun 1950. Beliau juga pernah dilantik sebagai ketua Jawatankuasa Panitia Rumah Melayu, satu jawatankuasa di bawah PPS yang bertanggungjawab berusaha mengumpulkan dana bagi pembinaan sebuah bangunan asrama khusus untuk pelajar-pelajar Semenanjung Tanah Melayu. Ketika beliau mentadbir PPS, usaha mengumpul dana dari negeri-negeri Persekutuan Tanah Melayu untuk pembinaan asrama begitu giat dijalankan. Beliau yang aktif dalam kegiatan politik semasa menuntut di Mesir juga merupakan presiden pertama Lembaga Pembela Malaya (LPM), sebuah badan yang ditubuhkan oleh pelajar Melayu di Mesir yang aktif menuntut kemerdekaan Persekutuan Tanah Melayu daripada British. Sekembalinya ke tanah air, beliau berkhidmat sebagai pensyarah dan juga setiausaha Kolej Islam Malaya di Klang. Oleh sebab ketinggian ilmu dan kepakarannya dalam bidang agama, Universitas Sawerigading, Indonesia telah menganugerahkan gelaran profesor kepada beliau. Lihat Abu Hanifah Haris \& Mohammad Redzuan Othman, "Zulkifli Muhammad dan Perjuangan Politik Berteraskan Islam, 1955-1964”, Jurnal Usuluddin, Bil. 37, 2013, hlm. 83-92.

${ }^{21}$ Undang-Undang Tubuh Persekutuan Melayu Mesir, Bab Pertama, Fasal (1) dalam SP 142, Persekutuan Melayu Mesir, Himpunan Undang-Undang dan Peraturan-Peraturan Kerja. Lihat juga Bab Pertama, Fasal (1) dalam Undang-Undang Tubuh PMRAM, Kaherah: PMRAM, Oktober 1992, hlm. 2.

${ }^{22}$ Muhammad Ghazali bin Abdul Wahid merupakan pelajar lulusan Kuliyyah Syariah di Universiti al-Azhar. Beliau dilahirkan di Beruas, Perak dan dibesarkan di Bukit Chandan, Perak. Beliau melanjutkan pengajian ke Mesir pada tahun 1949 dan pulang ke tanah air pada tahun 1959 setelah tamat pengajian. Beliau juga merupakan suami kepada Mariam, yang juga pelajar lulusan Mesir dan merupakan anak kepada Shaykh Muhammad Idris al-Marbawi. Lihat: "Mahasiswa dari Mesir Melawat Sekolah Ugama", Berita Harian, 13 Oktober 1959, hlm. 7.

${ }^{23}$ Setiausaha Eksekutif Jawatankuasa Pusat Sambutan Kemerdekaan kepada Yang Dipertua PMM, 14 Januari 1957, dalam M30, Merdeka Celebrations in The UK, Australia, New Zealand \& Egypt.

${ }^{24}$ Dalam satu laporan akhbar Berita Harian pada tahun 1961, dilaporkan bahawa pejabat PMM terletak di dalam bangunan Hotel Palestine yang disewa dengan kadar bayaran \$320 (Malaya) sebulan. Kerajaan Persekutuan Tanah Melayu ada mengirimkan wang bantuan sebanyak \$640 (Malaya) setiap bulan kepada pihak PMM bagi membantu kewangan PMM. Separuh daripada wang tersebut untuk bayaran sewa pejabat PMM dan separuh lagi untuk perbelanjaan bulanan PMM. Lihat: “Asrama Pelajar-Pelajar Melayu Mesir," Berita Harian, 1 Oktober 1961, hlm. 6. 
${ }^{25}$ Undang-Undang Tubuh Persekutuan Melayu Mesir, Bab Pertama, Fasal (2) dalam SP 142, Persekutuan Melayu Mesir, Himpunan Undang-Undang dan Peraturan-Peraturan Kerja,

${ }^{26}$ Realiti Gelombang Aura Mahasiswa dan Hak Kita: “ARMA”, hlm. 6 \& 9.

${ }^{27}$ Lihat Lampiran 3, 4, 5 \& 6.

${ }^{28}$ Realiti Gelombang Aura Mahasiswa dan Hak Kita: “ARMA”, hlm. 6.

${ }^{29}$ Ibid., hlm. 9. Lihat juga "Students Told Before Leaving Stay Anti-Red”, Singapore Free Press, 28 Disember 1954, hlm. 3.

30 Realiti Gelombang Aura Mahasiswa dan Hak Kita: “ARMA”, hlm. 9. Lihat Lampiran 7. Lihat juga "Bandoeng Chosen for Meeting", The Straits Times, 15 Jun 1964, hlm. 2.

${ }^{31}$ Realiti Gelombang Aura Mahasiswa dan Hak Kita: "ARMA”, hlm. 9. Lihat juga Lampiran 8.

${ }^{32}$ Realiti Gelombang Aura Mahasiswa dan Hak Kita: “ARMA”, hlm. 7 \& 9.

${ }^{33}$ Ibid. Lihat Lampiran 9. Menerusi temu bual dengan Tan Sri Wan Mokhtar pada 2 November 2015 di kediamannya di Shah Alam, menurutnya pelajar-pelajar Melayu tidak dibenarkan menyertai pertempuran di medan perang. Mereka hanya dibenarkan menyertai latihan penggunaan senjata perang dan perbarisan kawat sukarelawan melalui Kota Kaherah sahaja bagi menaikkan semangat para pemuda Mesir untuk menyertai pasukan ketenteraan. Pengalaman beliau ketika itu juga ada diceritakan dalam Wan Mokhtar Ahmad, Muzakkirah, Kuala Lumpur: Utusan Publications \& Distributors Sdn. Bhd., hlm. 26-27.

${ }^{34}$ Realiti Gelombang Aura Mahasiswa dan Hak Kita: “ARMA”, hlm. 7 \& 9. Lihat juga Lampiran 10.

${ }^{35}$ Realiti Gelombang Aura Mahasiswa dan Hak Kita: “ARMA”, hlm. 7 \& 9.

36 "Petualang-Petualang Lempar Batu Sembunyi Tangan Berada di Belakang Krisis Pelajar-Pelajar Melayu Mesir”, Berita Harian, 18 Jun 1961, hlm. 8.

${ }^{37}$ Ahmad Shahbari @ Sobri bin Salamon (1942-) merupakan Tokoh Ulama Bestari Negeri Selangor pada tahun 2000 dan juga Tokoh Maal Hijrah Negeri Selangor pada tahun 2001. Beliau yang berasal dari Kampung Sungai Purun (Kg. Batu Tiga), Semenyih, Selangor merupakan seorang ahli akademik dan juga pernah memegang jawatan-jawatan penting dalam pelbagai institusi perbankan di Malaysia. Beliau melanjutkan pengajian Ijazah Sarjana Muda Syariah di Universiti al-Azhar, Mesir pada tahun 1960 sehingga tahun 1970 sebelum melanjutkan pengajian Ijazah Sarjana dalam bidang ekonomi di Universiti Fairlaigh Dickinson, Amerika Syarikat dan seterusnya ke peringkat Ijazah Doktor Falsafah $(\mathrm{PhD})$ dalam bidang sejarah moden Timur Tengah di Universiti New York, Amerika Syarikat. Ketika dalam pengajian di Mesir, beliau terlibat dengan konflik dalaman PMM berkaitan hal keanggotaan persatuan pada tahun 1961. Walau bagaimanapun, selepas selesai konflik tersebut beliau menjadi seorang anggota PMM yang aktif dan lantang bersuara. Lihat: Ahmad Shahbari @ Sobri Salamon, Dendang Perantau, Memoir Seorang Ahli Akademik, Bandar Baru Bangi: Persatuan Bekas Mahasiswa-Mahasiswa Islam Timur Tengah, 2013.

${ }^{38}$ Ibid., hlm. 75 .

${ }^{39}$ Kenyataan ini turut disokong oleh Tan Sri Wan Mokhtar Ahmad, bekas Yang Dipertua PMM pada tahun 1959-1961 menerusi temu bual dengan beliau di kediamannya di Shah Alam, pada 2 November 2015. Menurut Tan Sri Wan Mokhtar, PMM telahpun wujud di Mesir sejak pertama kali beliau menjejakkan kaki di Mesir pada tahun 1954. Ini kerana PMM yang ketika itu di bawah pimpinan Ibrahim Ahmad Sharif adalah persatuan Melayu di Kaherah yang menguruskan urusan ketibaan dan pengajiannya di Mesir.

${ }^{40}$ Terdapat lima bahagian Peraturan Kerja. Peraturan Kerja (1) berkenaan tatatertib persidangan-persidangan dalam PMM. Peraturan Kerja (2) pula berkenaan cara-cara menyusun, menguatkuasa dan membatalkan Peraturan Kerja PMM. Peraturan Kerja (2) ini terbahagi kepada tujuh peraturan iaitu kuasa Mesyuarat Agung, kuasa Badan Pengurus, Lembaga Peraturan Kerja, Badan Perancang, orang-perseorangan, jalan kuatkuasa peraturan dan hukum am. Peraturan Kerja (3) berkenaan perlantikan, penolakan, pemecatan, penarikan diri anggota-anggota Pengurus, badan-badan dan pegawai-pegawai PMM. Peraturan Kerja (4) ialah berkenaan peraturan Majallah Dinding PMM. Peraturan Kerja (5) pula ialah berkenaan peraturan kerja Badan Perancang. Lihat Peraturan Kerja (1), (2), (3), (4) \& (5) dalam SP 142, Persekutuan Melayu Mesir, Himpunan UndangUndang dan Peraturan-Peraturan Kerja.

${ }^{41}$ Peraturan Kerja (3), Bahagian (D), No. 22 dalam SP 142, Persekutuan Melayu Mesir, Himpunan UndangUndang dan Peraturan-Peraturan Kerja. Walau bagaimanapun, tidak semestinya anggota Badan Pengurus terdiri daripada 11 orang. Pada tahun 1962, seramai 20 orang anggota telah dilantik untuk menganggotai Badan Pengurus. Lihat SP 142, Minit Mesyuarat Agong Tahun 1961, hlm. 15-16.

${ }^{42}$ SP 142/9, Warta Persekutuan Melayu Mesir, Bil. 2, 1 Mac 1962, hlm. 2.

${ }^{43}$ SP 142/9, Warta Persekutuan Melayu Mesir, Bil. 4, 1 April 1962, hlm. 2.

${ }^{44}$ Peraturan Kerja (2), Bahagian (B), No. 7 dalam SP 142, Persekutuan Melayu Mesir, Himpunan UndangUndang dan Peraturan-Peraturan Kerja.

${ }^{45}$ Peraturan Kerja (5), Bab (1), No. (1) dalam SP 142, Persekutuan Melayu Mesir, Himpunan Undang-Undang dan Peraturan-Peraturan Kerja. 
${ }^{46}$ Peraturan Kerja (5), Bab (1), No. (3) dalam SP 142, Persekutuan Melayu Mesir, Himpunan Undang-Undang dan Peraturan-Peraturan Kerja.

${ }^{47}$ Peraturan Kerja (5), Bab (1), No. (4) dalam SP 142, Persekutuan Melayu Mesir, Himpunan Undang-Undang dan Peraturan-Peraturan Kerja.

${ }^{48}$ Peraturan Kerja (2), Bahagian (B), No. 11 dalam SP 142, Persekutuan Melayu Mesir, Himpunan UndangUndang dan Peraturan-Peraturan Kerja.

${ }^{49}$ Peraturan Kerja (2), Bahagian (c), No. 15 dalam SP 142, Persekutuan Melayu Mesir, Himpunan UndangUndang dan Peraturan-Peraturan Kerja.

${ }^{50}$ Peraturan Kerja (2), Bahagian (c), No. 16 dalam SP 142, Persekutuan Melayu Mesir, Himpunan UndangUndang dan Peraturan-Peraturan Kerja.

${ }^{51}$ SP 142/9, Warta Persekutuan Melayu Mesir, Bil. 1, 15 Februari 1962.

${ }^{52}$ Undang-Undang Tubuh Persekutuan Melayu Mesir, Bab Keempat, Fasal (38), Perkara (a) dan (b), dalam SP 142, Persekutuan Melayu Mesir, Himpunan Undang-Undang dan Peraturan-Peraturan Kerja,

${ }^{53}$ Badan Penerangan tahun 1962 merupakan pengasas Majalah Warta PMM.

${ }^{54}$ SP 142/9, Warta Persekutuan Melayu Mesir, Bil. 2, 1 Mac 1962, hlm. 2.

55 Firdaus Abdullah, "Mengapakah Umat Islam Mesti Tinggal Mundor? Hati dan Nadi Dunia Pelajar", Berita Harian, 11 Ogos 1963, hlm. 6.

${ }^{56}$ SP 142/9, Warta Persekutuan Melayu Mesir, Bil. 11, 1 Oktober 1962, hlm. 2.

${ }^{57}$ SP 142/9, Warta Persekutuan Melayu Mesir, Bil. 4, 1 April 1962, hlm. 3.

${ }^{58}$ SP 142/9, Warta Persekutuan Melayu Mesir, Bil. 16, 15 Disember 1962, hlm. 2 dan "Pelajar Dapat Kurniaan Mesir”, Berita Harian, 24 Februari 1964, hlm. 5.

${ }^{59}$ SP 142/9, Warta Persekutuan Melayu Mesir, Bil. 1, 15 Februari 1962, hlm. 1.

${ }^{60}$ SP 142/9, Warta Persekutuan Melayu Mesir, Bil. 2, 1 Mac 1962, hlm. 2.

${ }^{61}$ SP 142/9, Warta Persekutuan Melayu Mesir, Bil. 13, 1 November 1962, hlm. 2.

62 Kertas Kerja Berkenaan Bulan Bahasa Kebangsaan, SP 142/11, Persekutuan Melayu Mesir, Badan Pengetahuan, 1962; "Ramai Kunjongi Pameran Buku oleh Pelajar-Pelajar di Mesir," Berita Harian, 15 September 1962, hlm. 6 dan "Pelajar-Pelajar Melayu di Mesir Mengadakan Majlis Bulan Bahasa Kebangsaan," Berita Minggu, 24 Mac 1963, hlm. 5.

${ }^{63}$ SP 142/9, Warta Persekutuan Melayu Mesir, Bil. 3, 15 Mac 1962, hlm. 3.

${ }^{64}$ SP 142/9, Warta Persekutuan Melayu Mesir, Bil. 2, 1 Mac 1962, hlm. 2.

${ }^{65}$ SP 142/9, Warta Persekutuan Melayu Mesir, Bil. 11, 1 Oktober 1962, hlm. 1.

66 "Persekutuan Melayu Mesir Kalahkan Indonesia 5-3", Berita Harian, 18 Oktober 1961, hlm. 8, "Malaysia Johan Bola Sepak dan Badminton di Mesir", Berita Harian, 24 September 1963, hlm. 12. Lihat juga "Pertandingan untuk Rebut Piala Malaysia", Berita Harian, 12 September 1963, hlm. 2.

${ }^{67}$ Tugas-Tugas Anggaran Kerja Badan Kesenian dan Kebudayaan bagi Tahun 1961, Perkara (A) dalam SP 142/11, Persekutuan Melayu Mesir, Badan Pengetahuan 1962, (No. 4 dalam Fail BKK/PMM).

68 Tugas-Tugas Anggaran Kerja Badan Kesenian dan Kebudayaan bagi Tahun 1961, Perkara (B) dalam SP 142/11, Persekutuan Melayu Mesir, Badan Pengetahuan 1962, (No. 4 dalam Fail BKK/PMM).

${ }^{69}$ SP 142/9, Warta Persekutuan Melayu Mesir, Bil. 3, 15 Mac 1962, hlm. 1. Lihat juga: "Pelajar Dapat Kurniaan Mesir," Berita Harian, 24 Februari 1964, hlm. 5.

${ }^{70}$ Badan Politik PMM telah diwujudkan sejak tahun 1953 lagi yang dianggotai oleh Wan Abdul Kadir Ismail, Wan Hussein Azmi dan Hassan Salleh. Badan ini bertujuan untuk memperkenalkan perjuangan bangsa Melayu di Persekutuan Tanah Melayu demi membebaskan negara daripada jajahan British. Lihat Realiti Gelombang Aura Mahasiswa dan Hak Kita: “ARMA”, hlm. 6.

${ }^{71}$ Surat setiausaha PMM kepada ketua-ketua badan dan bendahari, 26 November 1958 dalam SP 142/10, Badan Pemandu Persekutuan Melayu Mesir (BPPMM 1/58).

72 Pindaan Tugas Badan Pemandu, Perkara (A) dalam SP 142/10, Badan Pemandu Persekutuan Melayu Mesir (BPPMM 1/58). Dalam keputusan Mesyuarat Agung PMM 1958 yang diadakan pada 18 Disember 1958, terdapat cadangan menghapuskan Badan Pemandu. Ini kerana menurut mereka, badan tersebut gagal dalam melaksanakan peranannya dan boleh membawa akibat buruk kepada PMM sendiri. Walaupun keputusan menghapuskan badan tersebut ditentang keras oleh bekas ketua badan tersebut yang terakhir iaitu Abdul Mohsein Salleh, namun keputusan tersebut tetap dijalankan. Menurut Abdul Mohsein Salleh, keputusan tersebut dibuat secara terburu-buru dan tidak mengambil kira pendapatnya sebagai bekas ketua badan tersebut. Tidak lagi ditemui sebarang rekod penubuhan dan perlantikan anggota Badan Pemandu PMM selepas tahun 1958. Lihat dokumen Program Mesyuarat Agung PMM Tahun 1958 dalam SP 142/10, Badan Pemandu Persekutuan Melayu Mesir (BPPMM 1/58). Lihat juga surat Abdul Mohsein Salleh kepada Yang Dipertua PMM, 20 Disember 1958, dalam SP 142/10, Badan Pemandu Persekutuan Melayu Mesir (BPPMM 1/58).

${ }^{73}$ Pindaan Tugas Badan Pemandu, Perkara (D) dalam SP 142/10, Badan Pemandu Persekutuan Melayu Mesir (BPPMM 1/58). 
${ }^{74}$ Shaykh Abdul Mohsein bin Salleh (1930-1986) merupakan mantan Mufti Wilayah Persekutuan Kuala Lumpur yang pertama (p. 1971-1984).

${ }^{75}$ SP 142/9, Warta Persekutuan Melayu Mesir, Bil. 17, 1 Februari 1963, hlm. 1.

${ }^{76}$ SP 142/9, Warta Persekutuan Melayu Mesir, Bil. 19, 1 Mac 1963, hlm. 4.

77 Jabatan Setiausaha Agong Persekutuan Melayu Mesir, Nama-Nama Anggota Persekutuan Melayu Mesir, dalam SP 142, Persekutuan Melayu Mesir, Himpunan Undang-Undang dan Peraturan-Peraturan Kerja.

${ }^{78}$ SP 142/9, Warta Persekutuan Melayu Mesir, Bil. 2, 1 Mac 1962, hlm. 1.

${ }^{79}$ SP 142/9, Warta Persekutuan Melayu Mesir, Bil. 4, 1 April 1962, hlm. 2.

${ }^{80}$ Panitia Rumah Melayu diwujudkan sejak tahun 1932 bagi merancang, merangka dan berusaha dalam merealisasikan impian pelajar-pelajar Tanah Melayu untuk mempunyai sebuah bangunan asrama sendiri. Panitia ini mengumpul dana dan berurusan dengan kerajaan Mesir dan kerajaan Tanah Melayu bagi mencapai matlamat tersebut. Matlamat panitia ini telah tercapai apabila bangunan asrama Rumah Melayu telah siap dibina dan didiami pada akhir tahun 1963.

${ }^{81}$ Cadangan Badan Pengurus: Mengesahkan Laporan Sasaran, Keputusan Mesyuarat Agong, 1 Oktober 1960, hlm. 1-4 dalam SP 142, Persekutuan Melayu Mesir, Himpunan Undang-Undang dan Peraturan-Peraturan Kerja. Panitia ini terdiri daripada seorang ketua, Wakil Ketua Satu, Wakil Ketua Dua, setiausaha, bendahari dan beberapa orang ahli jawatankuasa, sila lihat Ketua Badan Penerangan kepada anggota PMM, 10 Disember 1961, dalam SP 142, Persekutuan Melayu Mesir, Himpunan Undang-Undang dan Peraturan-Peraturan Kerja.

${ }^{82}$ SP 142/9, Warta Persekutuan Melayu Mesir, Bil. 4, 1 April 1962, hlm. 1.

${ }^{83}$ Setiausaha Panitia Menyemak Kembali Undang-Undang Tubuh PMM (PMKUTPMM) kepada Abdul Mohsein Salleh, dalam SP 142, Persekutuan Melayu Mesir, Himpunan Undang-Undang dan PeraturanPeraturan Kerja.

${ }^{84}$ SP 142/9, Warta Persekutuan Melayu Mesir, Bil. 25, 15 Ogos 1963, hlm. 2.

${ }^{85}$ SP 142/9, Warta Persekutuan Melayu Mesir, Bil. 2, 1 Mac 1962, hlm. 1 \& SP 142/9, Warta Persekutuan Melayu Mesir, Bil. 17, 1 Februari 1963, hlm. 2.

${ }^{86}$ Lihat Lampiran 1.

${ }^{87}$ Ketua Badan Pemandu yang juga Naib Yang Dipertua PMM kepada YM Dato’ Abdul Jalil Hassan, 4 April 1958, dalam SP 142/10, Badan Pemandu Persekutuan Melayu Mesir (BPPMM 1/58). Muhammad Kamil Suhaimi juga merupakan Ketua Badan Pemandu dari awal tahun 1958 sehingga awal bulan April 1958. Muhammad Kamil Suhaimi (1932-1990) merupakan pelajar Melayu dari Singapura lulusan Universiti al-Azhar dan Lincoln Inn, London. Beliau yang merupakan anak kepada Shaykh Fadhlullah Suhaimi pernah berkhidmat sebagai guru di Maahad al-Ma'arif dan Ahli Jawatankuasa Fatwa Majlis Ugama Islam Singapura (MUIS).

${ }^{88}$ Setiausaha Agung PMM kepada semua ketua badan dan bendahari, 26 November 1958, dalam SP 142/10, Badan Pemandu Persekutuan Melayu Mesir (BPPMM 1/58). Wan Mokhtar bin Wan Ahmad (1932-) merupakan bekas Menteri Besar Terengganu (1974-1999) dan juga pernah menyandang jawatan sebagai Naib Presiden UMNO peringkat kebangsaan (1984-1990).

${ }^{89}$ Siaran Badan Pemandu, 28 November 1958, dalam SP 142/10, Badan Pemandu Persekutuan Melayu Mesir (BPPMM 1/58). Siaran Badan Pemandu tersebut telah dihebahkan menerusi Badan Penerangan PMM.

${ }^{90}$ Lihat Lampiran 1.

${ }^{91}$ Sharif Putera, Sekali Angin Menderu, Kuala Terengganu: Persatuan Sasterawan Terengganu (PELITA), hlm. 54. Abdul Kader bin Talip (1929-2015) merupakan mantan Mufti Wilayah Persekutuan Kuala Lumpur yang ketiga (1991-1999).

${ }^{92}$ SP 142, Ishak Mohd. Rejab kepada Abdul Mohsein Salleh, 23 Jun 1961. Ishak Mohd. Rejab merupakan bekas pensyarah di Jabatan Pengajian Arab dan Tamadun Islam, Fakulti Pengajian Islam, Universiti Kebangsaan Malaysia (UKM).

${ }^{93}$ Setiausaha Agung PMM kepada Abdul Mohsein Salleh, 2 Oktober 1961, dalam SP 142, Persekutuan Melayu Mesir, Himpunan Undang-Undang dan Peraturan-Peraturan Kerja. Mohd. Zain bin Hj. Serudin (1936-) merupakan mantan Menteri Hal Ehwal Agama Islam Negara Brunei Darussalam yang pertama.

${ }^{94}$ SP 142, Naib Setiausaha Agung / Pemangku Setiausaha Agung kepada Abdul Mohsein Salleh, 1 Julai 1961.

95 "Badan Pelajar Mesir Harus Bubar Akibat Pertikaian Sama Sendiri; 3 Golongan Sekarang Saling Bertentangan Merunchingkan Krisis di Kalangan Penuntut,” Berita Harian, 21 Mei 1961, hlm. 5.

${ }^{96}$ Ibid.

97 Ketua Badan Penerangan kepada semua anggota PMM, 10 Disember 1961, dalam SP 142, Persekutuan Melayu Mesir, Himpunan Undang-Undang dan Peraturan-Peraturan Kerja.

${ }^{98}$ SP 142, Ketua Badan Sukan dan Perkelahan kepada Rumah Abdul Mohsein Salleh, 24 Mac 1961.

${ }^{99}$ SP 142, Ketua Badan Kebajikan PMM kepada Pn. Hj. Patimah bt. Hj. Hashim, 20 Jun 1961.

${ }^{100}$ SP 142, Ketua Badan Kesenian dan Kebudayaan kepada semua anggota PMM, 15 Mac 1961.

${ }^{101}$ Muhammad Taib Hassan (1929-1997) merupakan mantan Mufti Negeri Pahang yang keenam (1982-1997).

Beliau yang berasal dari Kg. Benta, Pekan, Pahang memulakan pendidikan awalnya di Sekolah Melayu 
Kampung Benta sebelum melanjutkan pengajian ke Kuliyyah Lughah wa al-Din di Pekan, Pahang pada tahun 1947. Beliau seterusnya melanjutkan pengajian ke Sekolah Maahad Kerajaan Arab Saudi di Makkah sehingga memperoleh Diploma Pendidikan sebelum menyambung pengajian Ijazah Sarjana Muda Syariah di Universiti al-Azhar, Mesir pada awal tahun 1960-an. Sekembalinya beliau ke tanah air pada tahun 1965, beliau berkhidmat sebagai guru di Kuliyyah Lughah wa al-Din sebelum dilantik sebagai Pemangku Pengetua pada tahun 1967. Setahun selepas itu, beliau dilantik pula sebagai Pegawai Penerangan dan Dakwah Negeri Pahang sebelum dilantik sebagai Mufti Negeri Pahang pada tahun 1982. Lihat: Azman Ab. Rahman, Zahari Mahad Musa, Nik Salida Suhaila Nik Saleh \& Adel M. Abdul Aziz, Biografi Mufti-Mufti Malaysia, Bandar Baru Nilai: Universiti Sains Islam Malaysia (USIM), 2008, hlm. 55.

${ }^{102}$ Muhd. Ali Harun merupakan mantan Pengetua Pusat Yayasan Pengajian Tinggi Islam di Nilam Puri, Kelantan.

103 Jaiz Hj. Anwar (1941-2009) merupakan mantan Ketua Dewan Pemuda Parti Islam Se-Malaysia (PAS) Pusat yang kelima (1968-1970).

104 SP 142/9, Warta Persekutuan Melayu Mesir, Bil. 1, 15 Februari 1962, hlm. 2. Untuk merujuk proses pemilihan calon-calon anggota Badan Pengurus tahun 1962, sila lihat SP 142, Minit Mesyuarat Agong PMM Tahun 1961. Mesyuarat Agong tersebut telah bersidang pada 2 Februari 1962 di pejabat PMM di Imarat Najrah al-Khalij, Shari' Port Said, Kaherah bermula jam 10 pagi kemudian berhenti sebentar pada jam 11.40 pagi untuk persiapan solat Jumaat. Mesyuarat tersebut disambung kembali pada jam 6.30 petang sehingga ditamatkan pada jam 2.35 pagi. Abdul Kader Talip telah dipilih untuk mempengerusikan Mesyuarat Agong tersebut dan Abu Bakar Hj. Mohammad telah dilantik sebagai Setiausaha Mesyuarat Agong.

${ }^{105}$ SP 142/9, Warta Persekutuan Melayu Mesir, Bil. 17, 1 Februari 1963, hlm. 2.

${ }^{106}$ Umar Ismail (Perlis) telah menyandang jawatan Yang Dipertua dari tahun 1964 sehingga tahun 1966. Ini bermakna beliau merupakan Yang Dipertua PMM yang terakhir dan juga Yang Dipertua Persekutuan Melayu Republik Arab Bersatu (PMRAB) yang pertama. Ini kerana pada tahun 1965, PMM telah bertukar nama sekali lagi kepada PMRAB.

${ }^{107}$ Ahmad Awang merupakan mantan Timbalan Presiden PAS dan juga mantan Presiden Persatuan Ulama Malaysia.

108 Othman bin Ishak (1936-) merupakan bekas pensyarah Pengajian Islam di Universiti Malaya dan juga mantan Pengarah Institut Agama Islam Kedah (INSANIAH).

${ }^{109}$ Fadzil Mohd. Noor (1937-2002) merupakan tokoh ulama dan juga mantan Presiden Parti Islam Se-Malaysia (PAS) (1989-2002). Beliau juga merupakan mantan Ketua Pembangkang dalam Parlimen Malaysia (19992002).

${ }^{110}$ Yahya Othman merupakan mantan Ahli Jawatankuasa Tertinggi PAS dan mantan Murabbi Tarbiah PAS.

111 "Pelajar-Pelajar Mesir Anjor Kongres Luar Negeri,” Berita Harian, 19 Februari 1964, hlm. 2.

112 “Krisis Pelajar-Pelajar Kita di Mesir”, Berita Harian, 17 Mei 1961, hlm. 5

${ }^{113}$ Ibid. Anggota kumpulan penentang yang dilucutkan keanggotaannya dari PMM ialah Ahmad Sabri Salamon. Beliau dilucutkan keanggotaannya setelah Badan Pengurus PMM mengadakan mesyuarat dan mendapati bahawa beliau cuba menjatuhkan keperibadian Yang Dipertua PMM (Wan Mokhtar Ahmad) dengan membuat tuduhan bahawa Wan Mokhtar sebagai seorang yang bacul dan 'menjual' persatuan dengan harga yang murah. Beliau juga menuduh Wan Mokhtar menganaktirikan pelajar-pelajar Melayu dari Persekutuan Tanah Melayu dengan lebih mengutamakan pelajar-pelajar Melayu dari Brunei. Lihat: "Badan Pelajar Mesir Harus Bubar Akibat Pertikaian Sama Sendiri”, Berita Harian, 21 Mei 1961, hlm. 5. Walau bagaimanapun, hasil keputusan Mesyuarat Agong Badan Pengurus yang bersidang pada 15 Mac 1962 telah menerima kembali permohonan Ahmad Sabri untuk kembali menjadi anggota PMM. Bahkan beliau dilantik menganggotai Panitia Mentafsir Undang-Undang Tubuh PMM. Lihat SP 142/9, Warta Persekutuan Melayu Mesir, Bil. 4, 1 April 1963, hlm. 1.

114 "Badan Pelajar Mesir Harus Bubar Akibat Pertikaian Sama Sendiri", Berita Harian, 21 Mei 1961, hlm. 5; “Tidak Ada Krisis Antara Pelajar-Pelajar Persekutuan Melayu Mesir", Berita Harian, 11 Jun 1961; "PetualangPetualang Lempar Batu Sembunyi Tangan Berada di Belakang Krisis Pelajar-Pelajar Melayu Mesir", Berita Harian, 18 Jun 1961, hlm. 8; Muhd. Noor Wahab, "Krisis Pelajar Melayu Mesir, Latar Belakang", Berita Harian, 9 Julai 1961, hlm. 4; Any Ahmad, "Menambah Kayu dalam Api yang Sedang Nyala Marak", oleh Berita Harian, 16 Julai 1961, hlm. 6.

${ }^{115}$ Wan Mokhtar Ahmad, Muzakkirah, Kuala Lumpur: Utusan Publications \& Distributors Sdn. Bhd., 2008, hlm. 27-28.

${ }^{116}$ Yang Dipertua PMM kepada Setiausaha Agung Jawatankuasa Pusat Sambutan Kemerdekaan, 29 Januari 1957, hlm. 1, dalam M30, Merdeka Celebrations in The UK, Australia, New Zealand \& Egypt.

117 Jabatan Setiausaha Agong Persekutuan Melayu Mesir, Nama-Nama Anggota Persekutuan Melayu Mesir, dalam SP 142, Persekutuan Melayu Mesir, Himpunan Undang-Undang dan Peraturan-Peraturan Kerja. Anggota-anggota wanita tersebut ialah Aminah bt. Salleh, Amnah bt. Yaakub, Fatimah bt. Abdul Ghani (Johor), Nik Zahrah bt. Yahya, Sharifah Ataiah bt. Hashim dan Salamah bt. Ahmad. 
${ }^{118}$ Undang-Undang Tubuh Persekutuan Melayu Mesir, dalam SP 142, Persekutuan Melayu Mesir, Himpunan Undang-Undang dan Peraturan-Peraturan Kerja.

${ }^{119}$ SP 142, Umar bin Othman kepada Abdul Mohsein Salleh, 4 Julai 1961.

${ }^{120}$ SP 142, Minit Mesyuarat Agung Tahun 1961, hlm. 9-10. Lihat juga Setiausaha Panitia Menyemak Kembali Undang-Undang Tubuh PMM (PMKUT) kepada Abdul Mohsein Salleh, t.t, dalam SP 142, Persekutuan Melayu Mesir, Himpunan Undang-Undang dan Peraturan-Peraturan Kerja.

${ }^{121}$ SP 142, Minit Mesyuarat Agung Tahun 1961, hlm. 10. Dalam Mesyuarat Agung tersebut juga yang berkaitan perbincangan mengenai Panitia Menyemak Kembali Undang-Undang Tubuh, terdapat cadangan bagi mengubah nama persatuan kepada Al-Jam'iyyah al-Malayuwiyyah bi al-Jumhuriyyah al-Arabiyyah al-Muttahidah (Persekutuan Melayu Republik Arab Bersatu - PMRAB). Ini bersesuaian dengan perubahan nama baharu Republik Mesir ketika itu yang berubah kepada Republik Arab Bersatu (UAR) setelah penggabungan Mesir dengan Syria dan Yaman. Walau bagaimanapun, cadangan tersebut ditolak. PMM hanya bertukar nama kepada PMRAB pada tahun 1965.

${ }^{122}$ Ibid.

${ }^{123}$ SP 142/9, Warta Persekutuan Melayu Mesir, Bil. 4, 1 April 1962, hlm. 1.

${ }^{124}$ SP 142/9, Warta Persekutuan Melayu Mesir, Bil. 8, 15 Ogos 1962, hlm. 2.

${ }^{125}$ SP 142, Penyata Badan Perancang Mengenai Penafsiran Undang-Undang Tubuh PMM, 20 Disember 1962. 
SENARAI LAMPIRAN:

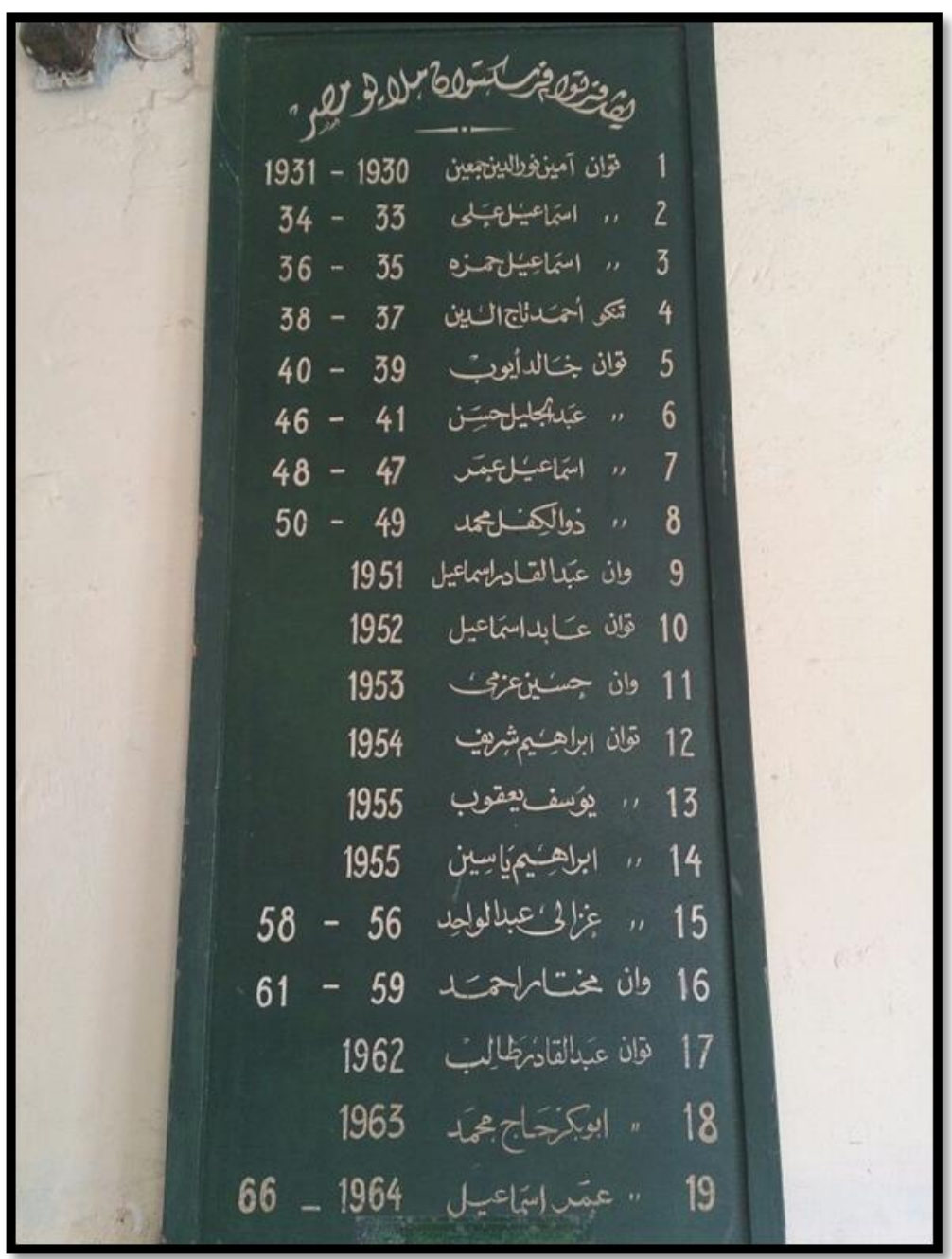

Lampiran 1

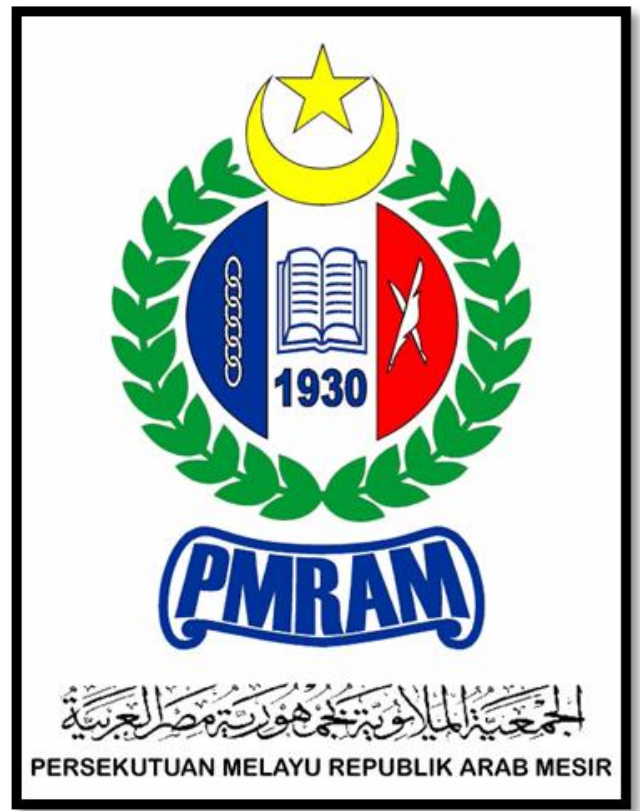

Lampiran 2 
:

THE MALAY ASSOCIATION

10, Sharia Sherif Pasha El-Kablr ABDIN - CAIRO

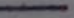

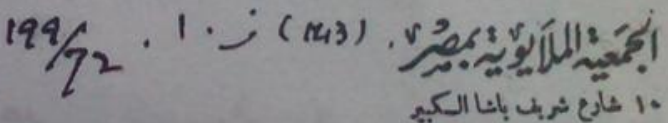

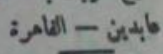

$$
\begin{aligned}
& \text { ر }
\end{aligned}
$$

No

Lampiran 3

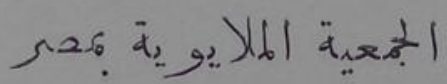

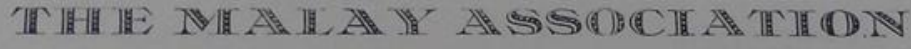
CAIRO

10. Sharto Sheril Feshn El Kabir

ABDIN - CAIRO

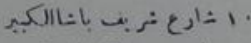
: allill

No. 018 dIm. PhI 2/57
29 th Jan. 1957

\section{Lampiran 4}

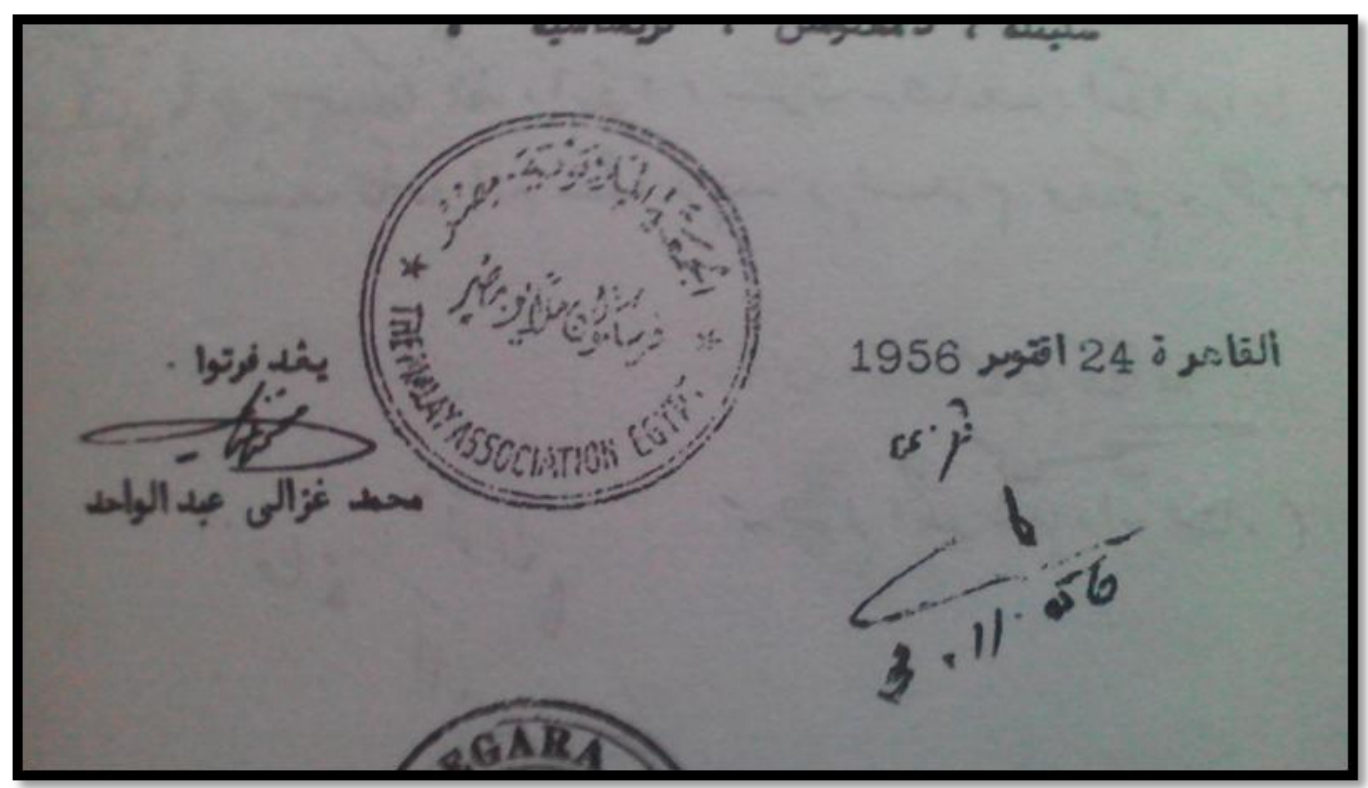

Lampiran 5 


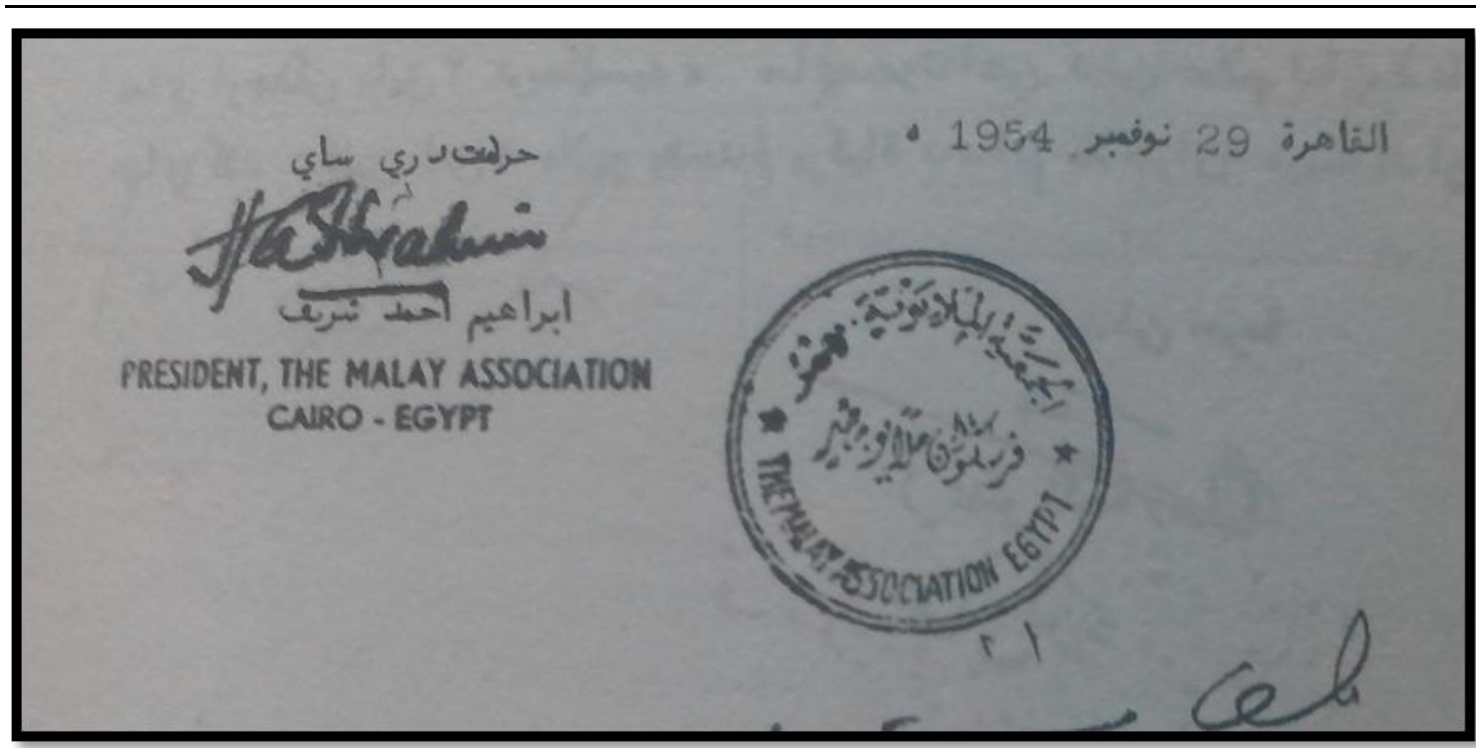

Lampiran 6

Lampiran 3 dan Lampiran 4 ialah salinan kepala setiap surat rasmi PMM, manakala Lampiran 5 dan 6 ialah salinan cop mohor PMM. Walaupun tercatat dalam Undang-Undang Tubuh PMM bahawa PMM secara rasminya diasaskan pada 5 Disember 1956, tetapi PMM telah menggunakan nama dan cop mohor PMM dalam dokumen mereka sejak tahun 1953 lagi. Sumber: Yang Dipertua PMM kepada Setiausaha Agung Jawatankuasa Pusat Sambutan Kemerdekaan, 29 Januari 1957, hlm. 1, dalam M30, Merdeka Celebrations in The UK, Australia, New Zealand \& Egypt dan Sharif Putera, Sekali Angin Menderu, Biografi Dato’ Seri Amar Di Raja Tan Sri Haji Wan Mokhtar bin Ahmad, Kuala Terengganu: Persatuan Sasterawan Terengganu (PELITA), 1999, hlm. $288 \& 299$.

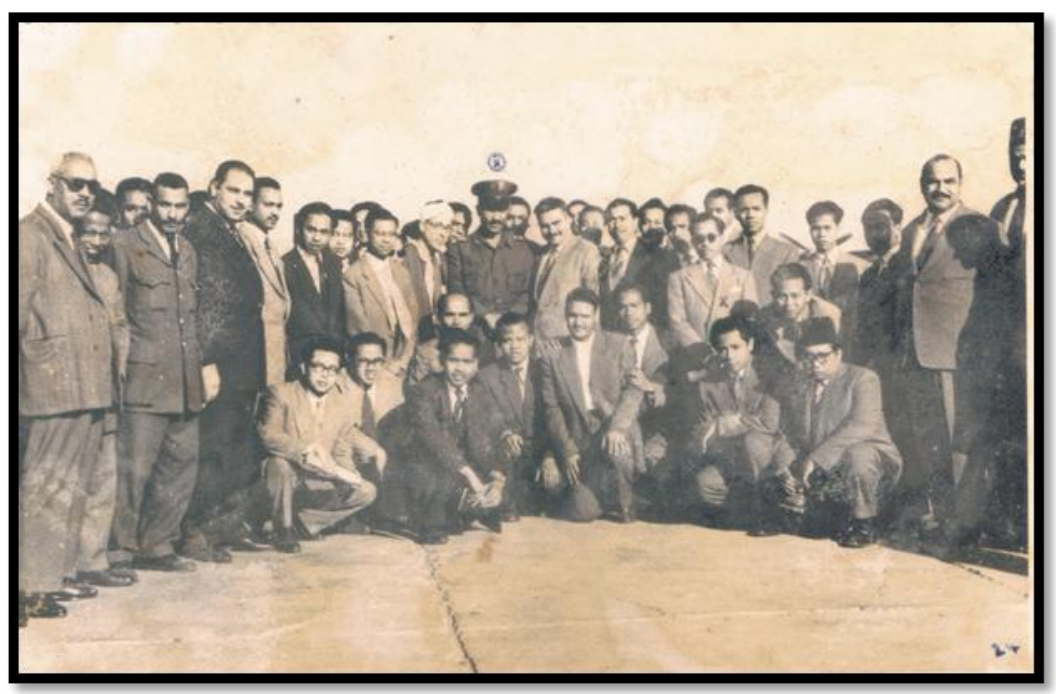

Lampiran 7 


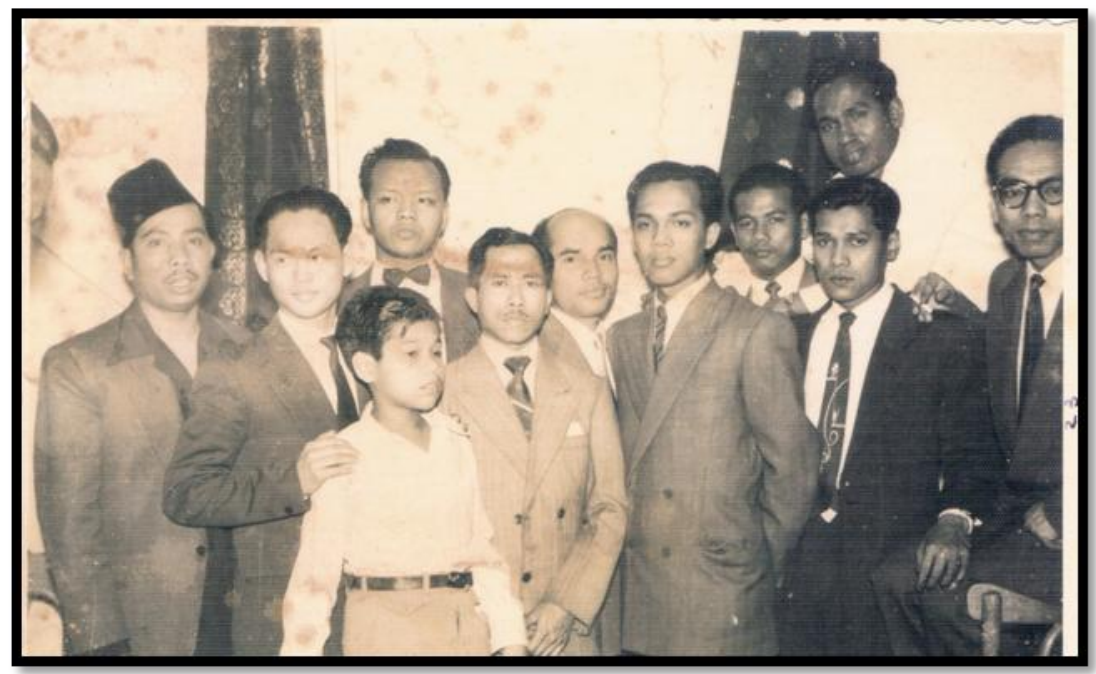

Lampiran 8

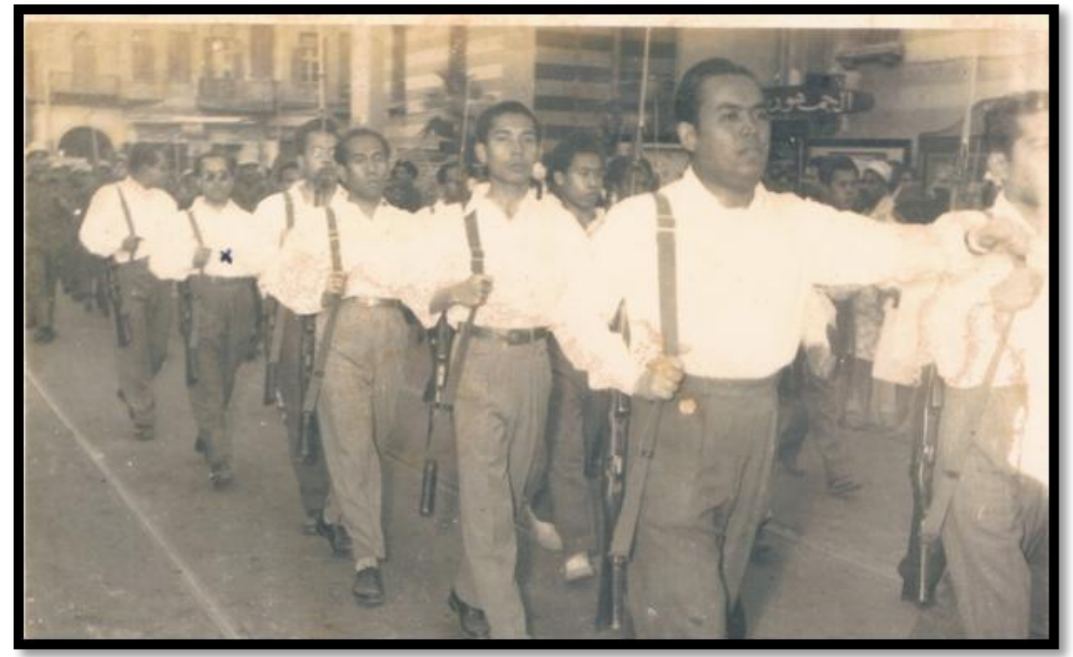

Lampiran 9

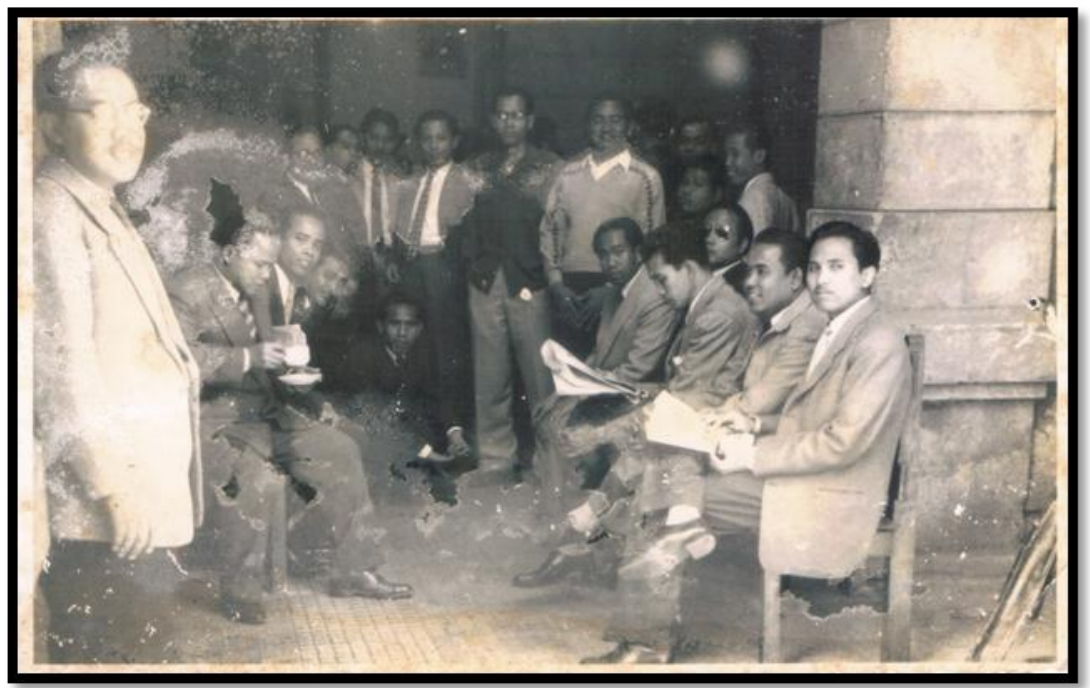

Lampiran 10 